\title{
Subcritical Water Extraction and Hydrolysis of Cod (Gadus morhua) Frames to Produce Bioactive Protein Extracts
}

\author{
Rodrigo Melgosa ${ }^{1}$, Marta Marques ${ }^{1}$, Alexandre Paiva ${ }^{1}\left(\mathbb{D}\right.$, Ana Bernardo ${ }^{2}\left(\mathbb{D}\right.$, Naiara Fernández ${ }^{2} \mathbb{D}$, \\ Isabel Sá-Nogueira ${ }^{3}$ and Pedro Simões ${ }^{1, *(\mathbb{D})}$
}

Citation: Melgosa, R.; Marques, M.; Paiva, A.; Bernardo, A.; Fernández, N.; Sá-Nogueira, I.; Simões, P. Subcritical Water Extraction and Hydrolysis of Cod (Gadus morhua) Frames to Produce Bioactive Protein Extracts. Foods 2021, 10, 1222. https://doi.org/10.3390/ foods10061222

Academic Editors: Joaquín

Gómez Estaca and

Oscar Martinez-Alvarez

Received: 3 May 2021

Accepted: 26 May 2021

Published: 28 May 2021

Publisher's Note: MDPI stays neutral with regard to jurisdictional claims in published maps and institutional affiliations.

Copyright: (C) 2021 by the authors Licensee MDPI, Basel, Switzerland. This article is an open access article distributed under the terms and conditions of the Creative Commons Attribution (CC BY) license (https:// creativecommons.org/licenses/by/ $4.0 /)$.
1 LAQV-REQUIMTE-Associated Laboratory for Green Chemistry (LAQV) of the Network of Chemistry and Technology (REQUIMTE), Departamento de Química, Faculdade de Ciências e Tecnologia, Universidade Nova de Lisboa, 2829-516 Caparica, Portugal; r.melgosa@fct.unl.pt (R.M.); martadiasmarques@gmail.com (M.M.); abp08838@fct.unl.pt (A.P.)

2 IBET-Instituto de Biologia Experimental e Tecnológica, Food \& Health Division, 2781-901 Oeiras, Portugal; ana.bernardo@ibet.pt (A.B.); naiara.fernandez@ibet.pt (N.F.)

3 UCIBIO-REQUIMTE, Applied Molecular Biosciences Unit (UCIBIO) of the Network of Chemistry and Technology (REQUIMTE), Departamento de Ciências da Vida, Faculdade de Ciências e Tecnologia, Universidade Nova de Lisboa, 2829-516 Caparica, Portugal; isn@fct.unl.pt

* Correspondence: pcs@fct.unl.pt; Tel.: +351-212-948-385

Abstract: The valorization of Atlantic cod (Gadus morhua) frames from a filleting industry was investigated using subcritical water extraction and hydrolysis (SBW) at different temperatures $\left(90,140,190\right.$ and $\left.250{ }^{\circ} \mathrm{C}\right)$ and 100 bar to obtain extracts rich in proteins, peptides and amino acids. Up to $57.7 \mathrm{~g}$ of extract per $100 \mathrm{~g}$ of codfish frames were obtained, with nearly total recovery of the protein fraction. At each temperature, protein extracts of decreasing molecular weight were obtained, according to SEC-GPC results. Most of the protein present in the raw material and extracts was collagen and collagen fragments, as suggested by the amino acid profile. Codfish SBW extracts did not show cytotoxicity in the range of concentrations tested and the protein extract obtained at the lowest temperature $\left(90^{\circ} \mathrm{C}\right)$ showed the highest anti-inflammatory potential in human intestinal epithelium cell model. The mineralized residue left after SBW treatment of cod frames was identified as practically pure, crystalline, hydroxyapatite, that may find applications in biomedical field and hardtissue engineering. This study shows the possible valorization of cod frames using green extraction methods such as SBW process to obtain protein extracts for food and nutraceutical applications.

Keywords: cod frames; subcritical water; fish protein hydrolysate; antioxidant activity; antiproliferative activity

\section{Introduction}

Atlantic codfish (Gadus morhua) is among the most important commercial fishes worldwide and the most consumed fish in Portugal. According to recent statistics, Portugal consumes around 70,000 tons per year [1]. This produces large quantities of by-products, mostly skin and bones, which might cause environmental problems when disposed of and should be adequately valorized.

Codfish frames (backbone with residual meat) are regarded as rich in minerals, such as calcium and phosphorus, and collagen proteins, although some carbohydrate and lipids are also found [2]. The bone tissue is mainly built up of an organic extra cellular matrix covered with hydroxyapatite (HAp), a calcium phosphate with chemical formula $\mathrm{Ca}_{10}\left(\mathrm{PO}_{4}\right)_{6}(\mathrm{OH})_{2}$. Both collagen and HAp can be used in a broad range of economically interesting applications as food ingredients, nutraceutics, or cosmetics [3]. Hence, there is a great potential for the conversion of cod frames into different bioproducts with high market value.

Collagen has a wide range of applications as emulsifier, foaming and gelling agent in the food, pharmaceutical, cosmetic, and photographic industries, among others. The most 
common sources are mainly from porcine or bovine origin. However, fish collagen is less restricted due to religious concerns and transmissible diseases, such as bovine spongiform encephalopathy (BSE) and food and mouth disease (FMD) [4]; thus, it has gained interest in the last years. Fish collagen can be also hydrolyzed to increase its digestibility in nutraceutical preparations and obtain active peptides with biologically active properties (antioxidative, antihypertensive and antimicrobial properties) [5]. Conventional methods for collagen extraction and hydrolysis use thermal treatments and strong acids or alkalis to increase collagen solubility, followed by salt precipitation to allow isolation. Loss of functional and nutritional properties due to the degradation of active molecules with the extreme temperatures and $\mathrm{pHs}$ involved, restrains the field of application of these hydrolysates to animal feed and fertilizers, where quality standards are lower [6]. Diluted organic acids such as acetic or citric acid have emerged as alternative extraction solvents, at the cost of increased processing times. Different authors report complex extraction methods consisting of pretreatment, extraction, and purification steps during several days to obtain relatively low yields [7], which is not affordable at industrial scale. Simultaneous or subsequent hydrolysis with proteases has been also introduced to obtain collagen fragments with increased solubility and potential biological properties. Jafarpour et al. [8] have recently investigated the valorization of cod frames by means of enzymatic extraction and hydrolysis. Other authors have proposed the intensification of the process through extrusion methods [7], ultrasound assisted extraction (UAE) [9], or the application of pulsed electric fields [10].

Calcium phosphates such as hydroxyapatite (HAp) present very high value due to their properties and technological applications, being well known for their use as bioceramics [11]. HAp is probably the most important calcium phosphate due to its high biocompatibility, and for this reason it is widely used in the medical field for hard tissue engineering [12]. Other applications of HAp include soil remediation [13], support for nanometallic catalysts [14], and development of fire-proof materials [15]. Most of the HAp and other calcium phosphates are currently produced by chemical synthesis, using different methods [11]. However, natural by-products and biowastes have been also investigated as a source for these materials, with economic and environmental advantages [11,16]. Bovine bones are extensively used to obtain HAp bioceramics [16], although other biowastes such as pig teeth and bones [17,18], chicken bones [19], eggshells [20], fish bones [21,22], and seafood shells [23] have been investigated as potential HAp sources. Different methods for HAp production from biowastes have been explored, such as hydrothermal conversion of calcified materials with phosphorus precursors [16], enzymatic hydrolysis [24], extraction with ionic liquids [25], and the most common thermal treatment at temperatures of $600-1200{ }^{\circ} \mathrm{C}$. The thermal decomposition method is simpler and cost-effective and has reached commercial status [11]. However, collagen proteins and other valuable compounds that might be present in the raw material are destroyed. Hence, previous extraction steps are necessary for an integral valorization of bone residues.

Subcritical water hydrolysis (SBW) represents a green alternative to both protein extraction and hydrolysis processes and HAp production through conventional chemical synthesis or thermal decomposition. SBW uses water at $100-274^{\circ} \mathrm{C}$ and pressure above saturation value but less than critical value. At these conditions, the dielectric constant of water decreases with increasing temperature due to hydrogen bond dissociation, allowing water to act as an effective solvent for moderately polar to non-polar substances. Additionally, the ionic product of water $\left(\mathrm{K}_{W}\right)$ increases with temperature, being three orders of magnitude higher than that at ambient conditions. This leads to the increase of hydronium and hydroxide ions concentrations and allows water to act as an acid or base catalyst, facilitating the hydrolysis of lignocellulosic polymers and proteins to smaller oligomers and peptides, without the use of additional catalysts $[26,27]$.

SBW has been widely investigated as a green method for biomass conversion, hemicellulose fractionation and extraction of phenolics [28]. However, SBW can be also applied to proteinaceous materials such as fish and fish wastes, obtaining amino acids and small 
peptides with interesting physicochemical and bioactive properties. Yoshida et al. [29] reported the SBW of fish meat from horse mackerel in a batch reactor, sequentially producing amino acids, organic acids, and fish oil when increasing temperature from 200 to $400{ }^{\circ} \mathrm{C}$. Other authors have also investigated the SBW of fish waste from different origins, such as white croaker entrails [30,31], bonito [31], squid viscera [32,33], or mackerel meat [34], bones and skin [35,36], among others. Ueno et al. [37] investigated the production of antihypertensive peptides through continuous SBW at $160-200^{\circ} \mathrm{C}$ and 20 bar, using cold-water fish gelatin as a fish waste model. Cho et al. [38] studied the production of shrimp (Penaeus japonicus) hydrolysates through a batch SBW process at $100-200{ }^{\circ} \mathrm{C}$ and evaluated their physicochemical and biofunctional properties, finding strong free-radical scavenging and antioxidant activities that increased with temperature up to $200{ }^{\circ} \mathrm{C}$. Ahmed and Chun [39] compared the hydrolysates obtained from tuna skin and from previously isolated tuna skin collagen through SBW process at $150-300{ }^{\circ} \mathrm{C}$ and $50-100$ bar. Maximum antioxidant and antimicrobial activities were found at $280^{\circ} \mathrm{C}$ and 80 bar for both materials, although hydrolysates from previously isolated collagen showed better results. Asaduzzaman et al. [35] reported the production of bioactive low-molecular-weight peptides from mackerel (Scomber japonicus) bone and skin, through a combination of pepsin assisted extraction of collagen and subsequent SBW of the extracts. SBW process was able to increase the antioxidant activity of the extracts, compared to the initially isolated collagen. In a previous work [40], we have recently applied a sequential supercritical fluid extraction and SBW process to the fractionation of sardine (Sardina pilchardus) waste into a fish oil rich in omega-3 polyunsaturated fatty acids, and a fish protein hydrolysate fraction rich in peptides and amino acids. Bioactive properties of the hydrolysates were affected by the temperature. The highest antioxidant activity and in vitro antiproliferative effect were found in the extracts obtained at the highest temperature studied, of $250{ }^{\circ} \mathrm{C}$. In all these works, the molecular profile of the hydrolysates showed that low-molecular-weight peptides are associated with the biofunctional activity of the extracts.

Other authors have applied the SBW process to completely remove protein and organic compounds from bone materials, focusing on the production of HAp from the deproteinized residue. Barakat et al. [41] obtained pure HAp nanoflakes from bovine bones by SBW treatment at $275^{\circ} \mathrm{C}$ and holding time $1 \mathrm{~h}$, although less crystallinity was obtained with SBW method compared to conventional direct heating treatment at $750-1200{ }^{\circ} \mathrm{C}$. SBW was also used for the deproteinization of shrimp cephalotorax wastes, obtaining highly pure calcareous chitin and promoting the formation of HAp nanocrystals with needle and flake shapes [42].

In this work, the extraction and hydrolysis of protein from cod frames and the simultaneous isolation of HAp using subcritical water have been investigated. To date, SBW process has been applied to the extraction and hydrolysis of collagen from different fish and fish wastes [29-40]. However, the production of HAp from these sources is scarcely reported and no mention has been found in the literature about the simultaneous collagen and HAp isolation from bone materials. Thus, the aim of this study was to isolate the main components of the cod frames and characterize their potential application as functional ingredients, to promote a more effective use of the waste generated during codfish processing.

\section{Materials and Methods}

\subsection{Materials}

Atlantic codfish (Gadus morhua) frames resulting from the industrial fish filleting process and consisting of the fish backbone and adhered muscle were provided by Pascoal and Filhos S.A. (Gafanha da Nazaré, Portugal). Each batch of fish waste was received fresh, immediately lyophilized, and kept at $-20^{\circ} \mathrm{C}$. Prior to experiments, samples were grinded (IKA Tube-Mill Control, IKA ${ }^{\circledR}$-Werke GmbH \& Co. KG, Staufen, Germany) and manually crushed to a fine powder (ca. $5 \mathrm{~mm}$ ). During this process, bones from different 
fish and from different parts of the same fish were mixed, to ensure that the samples were as homogenous as possible.

Lowry reagent, $2 \mathrm{~N}$ Folin-Ciocalteu's reagent, Bovine Serum Albumin (BSA) standard, phenol (99\%), $\mathrm{D}(+)$-glucose monohydrate, Bradford reagent and Lipopolysacccharides from Escherichia coli O55:B5 (LPS) were obtained from Sigma-Aldrich (Saint Louis, MO, USA). Human colorectal adenocarcinoma cell lines, Caco-2 and HT-29 were obtained from Deutsche Sammlung von Mikroorganismen und Zellkulturen (Braunschweig, Germany) and American Type Culture Collection (Manassas, VA, USA), respectively. Cell culture media (Dulbecco's Modified Eagle Medium, DMEM, and Roswell Park Memorial Institute, RPMI) and supplements (heat inactivated Fetal Bovine Serum, FBS, and non-essential amino acids, NEAA) were purchased from Invitrogen (Gibco, Invitrogen Corporation, Paisley, UK). CellTiter 96 Aqueous One Solution Cell Proliferation Assay (MTS) was obtained from Promega (Madison, WI, USA). Human IL-8 (CXCL8) Mini TMB ELISA Development Kit and TNF- $\alpha$ human recombinant were obtained from Peprotech (London, UK). Human IL-1 $\beta$ was obtained from Sino Biological (Düsseldorf, Germany). All other reagents and solvents used in the present study were of analytical grade and purchased from available suppliers.

\subsection{Subcritical Water Extraction and Hydrolysis (SBW)}

The subcritical water hydrolysis (SBW) of codfish frames was performed in a lab-scale apparatus described in previous publications [27]. Briefly, it consists of a distilled water reservoir, a Knauer 1800 high-pressure pump (Knauer Wissenschaftliche Geräte GmbH, Berlin, Germany), and a high-pressure reactor (High Pressure Equipment Co., Erie, PA, USA) with $510 \mathrm{~mm}$ length, $50 \mathrm{~mm}$ O.D., and $26 \mathrm{~mm}$ I.D., placed in a Nabertherm TR 240 electrical oven (Nabertherm GmbH, Lilienthal, Germany). Pressure of the system was controlled by a Tescom back-pressure regulator (BPR). Water mass flow and total mass of water fed to the system was recorded by means of a Rheonik RHM 007 mass flow meter (Rheonik Messtechnik GmbH, Odelzhausen, Germany).

In a typical experiment, $60 \mathrm{~g}$ of grinded codfish frames were loaded into the reactor, which was subsequently placed in the electrical oven and connected to the high-pressure circuit. Then, the pump was turned on at a flow rate of $10 \mathrm{~mL} / \mathrm{min}$ and the BPR was set at 100 bar to pressurize the system. When pressure reached $100 \mathrm{bar}$, the BPR opened and extract collection started, initiating the experiment. The preheating wires and the electrical oven were turned on at that point, and outlet temperature was increased from ambient conditions to $250{ }^{\circ} \mathrm{C}$. Samples were continuously collected in different flasks at specific target temperatures $\left(90,140,190\right.$ and $250^{\circ} \mathrm{C}$ ), which were maintained constant for $30 \mathrm{~min}$. For each sample, $25 \mathrm{~mL}$ were taken in triplicate, lyophilized, and weighed to calculate the extraction yield. The rest were frozen and kept at $-18{ }^{\circ} \mathrm{C}$ for further analysis. The residue that remained in the reactor after SBW experiments was washed with water, dried at $105{ }^{\circ} \mathrm{C}$ overnight, weighed and stored at $4{ }^{\circ} \mathrm{C}$ for further analysis.

\subsection{Proximate Composition}

Moisture was determined in a Kern DAB 100-3 thermogravimetric balance (Kern \& Sohn $\mathrm{GmbH}$, Balingen, Germany) at $105^{\circ} \mathrm{C}$. Ash content was gravimetrically analyzed through calcination in a muffle at $5500^{\circ} \mathrm{C}$ during $4 \mathrm{~h}$.

The protein content was determined by elemental analysis of nitrogen in a Flash EA 1112 CHNS analyzer (Thermo Fisher Scientific, Marietta, OH, USA), applying an appropriated nitrogen-to-protein conversion factor (NPCF).

A modified Lowry method [40] was also used to provide a second measurement of the protein content of codfish frames and protein extracts. Protein extraction from codfish frames was performed by alkaline hydrolysis with $4.2 \mathrm{M} \mathrm{NaOH}$ at $95^{\circ} \mathrm{C}$ during $1 \mathrm{~h}(\mathrm{~S}: \mathrm{L}=1: 20)$. Lyophilized protein extracts were redissolved in distilled water at a known concentration. Absorbance at $750 \mathrm{~nm}$ was read in a Genesys 50 spectrophotometer (Thermo Fisher Scientific, Marietta, OH, USA) and protein concentration in the samples was cal- 
culated based on a calibration curve made with BSA standard at concentrations ranging from 40 to $400 \mu \mathrm{g} / \mathrm{mL}$. Blank runs were also performed with distilled water instead of the protein sample.

Fat content was measured through the Bligh and Dyer [43] method. Soxhlet extraction with $n$-hexane was also performed in order to estimate the amount of non-polar lipids, following the method described by Pedras et al. [27]. Total sugars were determined by phenol-sulphuric acid colorimetric method, which is described elsewhere [27].

\subsection{Amino Acid Profile}

The amino acid profile of codfish frames and protein extracts obtained after SBW process was analyzed using a Dionex ICS-3000 high-performance liquid chromatographyion chromatography (HPLC-IC) system (Thermo Fisher Scientific, Marietta, OH, USA). The chromatographic separation was carried out at $30^{\circ} \mathrm{C}$ in a Dionex AminoPac PA10 IC column $(250 \times 4 \mathrm{~mm})$, with a $50 \times 4 \mathrm{~mm}$ pre-column. Detection was performed in an electrochemical (ED) detector. Solvent flow was $0.8 \mathrm{~mL} / \mathrm{min}$ and gradient elution was achieved with solvents (S) S1: water, S2: $250 \mathrm{mM} \mathrm{NaOH}$, S3: 1 M sodium acetate, S4: $0.1 \mathrm{M}$ acetic acid. The course of the gradient was as follows: elution time $(t)=0: 76 \% \mathrm{~S} 1,24 \% \mathrm{~S} 2$; $\mathrm{t}=8 \mathrm{~min}: 64 \% \mathrm{~S} 1,36 \% \mathrm{~S} 2 ; \mathrm{t}=18 \mathrm{~min}: 40 \% \mathrm{~S} 1,20 \% \mathrm{~S} 2,40 \% \mathrm{~S} 3 ; \mathrm{t}=23 \mathrm{~min}: 14 \% \mathrm{~S} 1,16 \% \mathrm{~S} 2$, $70 \%$ S3; $\mathrm{t}=45 \mathrm{~min}: 100 \% \mathrm{~S} 4 ; \mathrm{t}=47.1 \mathrm{~min}: 20 \% \mathrm{~S} 1,80 \% \mathrm{~S} 2 ; \mathrm{t}=49.3 \mathrm{~min}: 76 \% \mathrm{~S} 1,24 \% \mathrm{~S} 2$ (maintained for $15 \mathrm{~min}$ ). Sample preparation consisted of an alkaline digestion with $4.2 \mathrm{M}$ $\mathrm{NaOH}$ for $24 \mathrm{~h}$ at $110{ }^{\circ} \mathrm{C}(\mathrm{S}: \mathrm{L}=1: 20)$. After proper neutralization and dilution, $10 \mu \mathrm{L}$ were injected and HPLC-IC analysis was performed in triplicate. Individual amino acids were identified and quantified using calibration curves constructed with the corresponding standard compounds and using norleucine as internal standard. All compounds were obtained from Sigma-Aldrich (Saint Louis, MO, USA).

Free amino acids present in the SBW extracts were determined following the same analytical procedure but omitting the alkaline digestion step. Amino acid profile of codfish frames was used to calculate a corrected nitrogen-to-protein factor, following the NREL protocols [44]. Additionally, the weight percentage of collagen in the codfish frames and the SBW extracts was estimated from the hydroxyproline content as in Equation (1) [45]:

$$
\% \text { collagen }=\% \text { Hyp } \times 7.46
$$

where \% Hyp is the weight percentage of hydroxyproline in each sample. This value was used to monitor the collagen purity of the extracts.

\subsection{Mineral Profile}

To evaluate the mineral composition and the potential presence of heavy metals in the codfish frames, the obtained protein extracts, and the isolated HAp, inductively coupled plasma-atomic emission spectrometry (ICP-AES) analysis was performed using a Horiba Jobin-Yvon Ultima ICP (Horiba Ltd., Kyoto, Japan), equipped with a $40.68 \mathrm{MHz}$ RF generator and a Czerny-Turner monochromator. Argon was used to generate the plasma. To prepare the samples, the mineralized residue from ash determination was dissolved in $6 \mathrm{M}$ nitric acid at a known concentration and subsequently diluted with distilled water.

\subsection{SDS-PAGE}

Sodium dodecyl sulfate-polyacrylamide gel electrophoresis (SDS-PAGE) of the protein extracts obtained after SBW process of codfish frames was conducted by the method of Laemmli [46], with some modifications, to separate the proteins by their molecular weight. The hydrolysates, $100 \mu \mathrm{g}$ protein of each sample, were mixed with the loading buffer (50 mM Tris- $\mathrm{HCl}, \mathrm{pH} 6.8,2 \%(w / v)$ SDS $(w / v), 10 \%$ glycerol $(v / v)$, and $0.01 \%(w / v)$ bromophenol blue), and then loaded onto two different polyacrylamide gels: (i) a $7.5 \%$ precast gel, and (ii) a 15\% resolving gel and $4.5 \%$ stacking gel. The electrophoresis was conducted at a constant voltage of $120 \mathrm{~V}$. After electrophoresis, the gel was stained with $0.25 \%(w / v)$ Coomassie Blue R-250 in $8 \%(v / v)$ acetic acid and $46 \%(v / v)$ ethanol for 
$30 \mathrm{~min}$ and subsequently destained with a solution containing $10 \%(v / v)$ acetic acid and $30 \%(v / v)$ ethanol. A molecular-weight protein marker (NZYColour Protein Marker II) (NZYTech, Lda.-Genes and Enzymes, Lisbon, Portugal) was used to estimate the mass of the protein bands.

\subsection{Size Exclusion-Gel Permeation Chromatography (SEC-GPC)}

The extracts obtained after SBW treatment of codfish frames were filtrated through nylon syringe filters $(0.22 \mu \mathrm{m}$ pore diameter, ALWSCI Corporation, Zhejiang, China) and submitted to size exclusion-gel permeation chromatography (SEC-GPC) to estimate their molecular mass distribution. The equipment used was a Knauer Smartline HPLC system. For each sample, $20 \mu \mathrm{L}$ were injected into a Phenomenex Yarra SEC-2000 column $(300 \times 7.8 \mathrm{~mm}$ i.d. $)$ maintained at a constant temperature of $25^{\circ} \mathrm{C}$, and eluted with $0.1 \mathrm{M}$ phosphate buffer ( $\mathrm{pH} 6.8$ ) including $0.025 \%$ sodium azide at a flow rate of $1.0 \mathrm{~mL} / \mathrm{min}$. The relative intensity of the eluate was monitored with a UV/Vis detector at $280 \mathrm{~nm}$. The retention times of molecular mass standards (Protein Standard Mix 69385 from Sigma-Aldrich (Saint Louis, MO, USA)) were used to calculate the molecular mass distribution of the SBW extracts according to the retention time of the different peaks present in the chromatogram.

\subsection{Cell Viability}

To evaluate the potential of codfish SBW extracts for nutraceutical applications, cell viability assays were performed with the SBW extracts obtained at different temperatures. Human colorectal adenocarcinoma cell lines, Caco-2, were cultured following previously described methods [47]. Firstly, cytotoxicity effects were assessed through MTS assay using confluent Caco-2 cells as a model of the human intestinal epithelium. Briefly, cells were seeded in 96-well plates at a density of $2 \times 10^{4}$ cells/well and allowed to reach confluence for 7 days. Subsequently, the cells were incubated for $24 \mathrm{~h}$ with the extracts diluted in culture medium (DMEM $+0.5 \%$ FBS $+1 \%$ NEAA). The range of concentrations tested was $0.39-50 \mathrm{mg} / \mathrm{mL}$. Cells incubated with only culture medium were considered as control. After $24 \mathrm{~h}$ of treatment, the medium was removed and cell viability was measured using MTS reagent, according to a previously described method [47]. Three independent experiments were performed in a microplate spectrophotometer at $490 \mathrm{~nm}$ (EPOCH 2, BioTek Instruments, Winooski, VT, USA). Cell viability was expressed in terms of percentage of viable cells relative to the control and half maximal effective concentration $\left(E_{50}\right)$ values were calculated from dose-response curves, as the concentration of sample necessary to decrease cell proliferation by $50 \%$.

\subsection{Anti-Inflammatory Potential of Hydrolysates}

Anti-inflammatory properties of codfish SBW extracts were tested in Caco-2 cell line. Cells were plated at a density of 100,000 cells $/ \mathrm{cm}^{2}$ and allowed to grow for 21 days, with medium (DMEM supplemented with 1\% NEAA, 10\% FBS and 1\% PS) renewed 3 times a week. On the 21st day cells were ready to be used as a model of inflammation of the intestinal mucosa. To mimic the inflammation, cells were stimulated for $48 \mathrm{~h}$ with a cocktail of cytokines ( $25 \mathrm{ng} / \mathrm{mL}$ IL-1 $\beta, 50 \mathrm{ng} / \mathrm{mL}$ TNF- $\alpha$ and $10 \mathrm{ng} / \mathrm{mL}$ LPS) and extracts diluted in medium (DMEM supplemented with $1 \%$ NEAA and $0.5 \%$ FBS). The extract concentration tested was $25 \mathrm{mg} / \mathrm{mL}$ since it did not show any cytotoxic effect. Cells incubated only with medium were considered as negative control and cells incubated with medium and the cocktail of cytokines were considered positive control. After $48 \mathrm{~h}$ of treatment the medium was collected and centrifuged at $2000 \times g$ for $10 \mathrm{~min}$. The supernatant was recovered and stored at $-80{ }^{\circ} \mathrm{C}$ until the ELISA.

\subsection{Quantification of IL-8}

According to the cocktail of cytokines used, ELISA was performed to detect the presence of IL-8. The assessment of the IL-8 levels in the supernatant were performed using the human IL-8 (CXCL8) Mini TMB ELISA Development Kit (Peprotech, London, 
UK), according to the protocol provided by the manufacturer. Briefly, one day prior to running the assay, 96-well plates were coated with the capture antibody. Following overnight incubation at room temperature, the plates were washed with wash buffer (PBS (Thermo Fisher Scientific, Marietta, OH, USA) containing 0.05\% Tween-20 (Sigma-Aldrich, St. Louis, MO, USA) and then incubated for $1 \mathrm{~h}$ at room temperature (RT) with block buffet (1\% BSA in PBS) to inhibit nonspecific binding. After washing, $100 \mathrm{~mL}$ of standard dilution or extracts was added to each well in triplicate and incubated for $2 \mathrm{~h}$ at RT. After washing the plates, $100 \mathrm{~mL}$ of detection antibody was added to each well. The plates were then incubated for $2 \mathrm{~h}$ at RT, and then washed again, followed by the incubation with $100 \mathrm{~mL}$ of streptavidin-horseradish peroxidase (HRP) conjugated for $30 \mathrm{~min}$ at RT. Next, after additional washing, 3,3',5,5'-tetramethylbenzidine (TMB) substrate solution was added and the plates were incubated in the dark at RT for the color development (approximately $20 \mathrm{~min}$ ). The reaction was stopped by the addition of $100 \mathrm{~mL}$ of HCL 1M, and the absorbance was measured at $450 \mathrm{~nm}$ with wavelength correction set at $620 \mathrm{~nm}$ in a microplate spectrophotometer (EPOCH 2, BioTek Instruments).

The results (mean \pm SD of at least three experiments) were expressed in percentage normalized to the positive control.

\subsection{Hydroxyapatite Isolation and Characterization}

The deproteinized residue remaining in the SBW reactor was dried and submitted to different instrumental techniques to determine the presence and purity of HAp. For comparison, the product obtained after direct heating of codfish frames at $550{ }^{\circ} \mathrm{C}$ during $5 \mathrm{~h}$, and the residue obtained after alkaline digestion $\left(4.2 \mathrm{M} \mathrm{NaOH}, 110{ }^{\circ} \mathrm{C}, 24 \mathrm{~h}\right.$, $\mathrm{S}: \mathrm{L}=1: 20$ ) were analyzed by the same instrumental techniques, Fourier Transform-Infrared (FT-IR) spectroscopy, X-ray diffraction (XRD), and Field Emission Gun Scanning Electron Microscopy (FEG-SEM)as follows.

Spectroscopic characterization of codfish frames, lyophilized protein extracts, and the remaining residue after SBW process was performed by FT-IR spectroscopy. The spectra between 4000 and $400 \mathrm{~cm}^{-1}$ of all the samples were recorded as $\mathrm{KBr}$ discs, using a Perkin-Elmer Spectrum Two FT-IR spectrometer (Waltham, MA, USA). KBr discs were pressed using $5 \mathrm{mg}$ of the sample mixed with $200 \mathrm{mg}$ of desiccated KBr. The FT-IR spectra of Calcium phosphate hydroxide (HAp) from the National Institute of Standards and Technology (NIST) was used as a reference standard [48]. Data about the phase and crystallinity of the samples from the remaining residue were determined by XRD using a benchtop X-ray Diffractometer Rigaku, model MiniFlex II, with $\mathrm{Cu}$ K- $\alpha$ radiation $\left(30 \mathrm{KV} / 15 \mathrm{~mA}\right.$ ) (Tokyo, Japan). Measurements were taken at a scan speed of $1^{\circ} / \mathrm{min}$ and $0.02^{\circ}$ steps, between 20 and $55^{\circ}$. The NIST standard for HAp (SRM 2910b [49]) was used to identify the phases and compare the samples. FEG-SEM was performed in a JEOL 7001F equipment (Jeol Ltd., Tokyo, Japan) with Oxford light elements and Energy-Dispersive Detector (EDS). Samples were gold-sputtered in Ar plasma prior to analysis.

\subsection{Statistical Analysis}

SBW experiments were duplicated. Analytical data are expressed as mean \pm standard deviation (SD) of triplicates. Significant differences were detected through one-way analysis of variance and Fisher's LSD test, using Statgraphics software (version 18 for Windows).

GraphPad Prism 6 software was used to calculate the EC50 values of cytotoxicity. Results of potential anti-inflammatory analyses are the averages of at least three independent experiments and are reported as mean $\%$ positive control \pm SD. Differences between the controls and the experimental concentrations were assessed using $t$-test $(p<0.05)$ using the GraphPad Prims 6 software. 


\section{Results and Discussion}

\subsection{Characterization of Raw Material}

The main results obtained in the characterization of the raw material are summarized in Table 1. As expected, protein and ash were the major components of codfish frames. Protein content was analyzed through several methods, obtaining differing results. The Lowry method gave the lowest protein content, with $38.9 \pm 2.7 \mathrm{~g} / 100 \mathrm{~g}$. The Lowry method is a widely used colorimetric technique based on the binding of the Folin-Ciocalteu's reagent with aromatic amino acids. Due to its simplicity and availability, it has been widely used for protein determination in food and food wastes. However, many compounds besides aromatic amino acids can react with the Folin-Ciocalteu's reagent, leading to strong interferences. In addition, the amino acid sequence of the protein also affects the analysis. In the case of codfish frames, where collagen is the major protein, the low concentration of aromatic amino acids can lead to underestimations of the protein content [50].

Table 1. Proximate composition, amino acid profile and main minerals found in codfish frames.

\begin{tabular}{|c|c|c|c|c|c|c|}
\hline \multirow{2}{*}{\multicolumn{2}{|c|}{$\begin{array}{c}\text { Proximate Composition } \\
(\mathrm{g} / 100 \mathrm{~g})\end{array}$}} & \multicolumn{3}{|c|}{ Amino Acid Profile } & \multirow{2}{*}{\multicolumn{2}{|c|}{$\begin{array}{c}\text { Mineral Profile } \\
(\mathrm{mg} / \mathrm{g})\end{array}$}} \\
\hline & & Amino Acid & $(\mathrm{mg} / \mathrm{g})$ & (\% rel.) & & \\
\hline Moisture & $5.4 \pm 0.1$ & Arginine (Arg) & $37.67 \pm 0.1$ & 8.1 & $\mathrm{Ca}$ & 143.0 \\
\hline Protein & $47.0 \pm 0.9$ * & Lysine (Lys) & $12.98 \pm 0.1$ & 2.8 & $\mathrm{Na}$ & 5.3 \\
\hline Lipids & & Alanine (Ala) & $58.52 \pm 1.8$ & 12.6 & $\mathrm{P}$ & 69.4 \\
\hline Total & $1.9 \pm 0.1$ & Threonine (Thr) & $16.00 \pm 0.5$ & 3.4 & $\mathrm{Mg}$ & 2.43 \\
\hline Neutral & $1.4 \pm 0.1$ & Glycine (Gly) & $75.52 \pm 0.7$ & 16.2 & $\mathrm{Zn}$ & 0.0351 \\
\hline Ash & $39.3 \pm 1.1$ & Valine (Val) & $19.66 \pm 0.1$ & 4.2 & $\mathrm{Fe}$ & 0.0073 \\
\hline \multirow[t]{2}{*}{ Carbohydrates } & $0.3 \pm 0.05$ & Serine (Ser) & $21.96 \pm 0.2$ & 4.7 & $\mathrm{Cr}$ & n.d. \\
\hline & & Proline (Pro) & $55.60 \pm 1.9$ & 12.0 & As & 0.0004 \\
\hline \multirow{11}{*}{ Collagen content } & $30.6 \pm 0.8$ & Hydroxyproline (Hyp) & $40.99 \pm 1.0$ & 8.8 & $\mathrm{Cd}$ & n.d. \\
\hline & & Leucine (Leu) & $18.58 \pm 0.6$ & 4.0 & $\mathrm{Hg}$ & 0.0001 \\
\hline & & Isoleucine (Ile) & $16.66 \pm 0.3$ & 3.6 & $\mathrm{~Pb}$ & 0.0003 \\
\hline & & Methionine (Met) & $12.85 \pm 0.2$ & 2.8 & & \\
\hline & & Histidine (His) & $11.68 \pm 0.05$ & 2.5 & & \\
\hline & & Phenylalanine (Phe) & $11.64 \pm 0.04$ & 2.5 & & \\
\hline & & Glutamic acid (Glu) & $19.40 \pm 0.4$ & 4.2 & & \\
\hline & & Aspartic acid (Asp) & $17.86 \pm 0.1$ & 3.8 & & \\
\hline & & Cysteine (Cys) & $1.28 \pm 0.1$ & 0.3 & & \\
\hline & & Tyrosine (Tyr) & $16.25 \pm 0.3$ & 3.5 & & \\
\hline & & Total & $465.1 \pm 8.5$ & 100.0 & & \\
\hline
\end{tabular}

n.d.: not detected; ${ }^{*}$ Determined by elemental analysis with a specific NPCF of $5.1 \pm 0.3$.

Determination of the protein content based on nitrogen analysis assumes that all nitrogen in the sample is protein-bound and all proteins have the same nitrogen content of $16 \%$, leading to the typical NPCF of 6.25 . With this method, protein content of codfish frames was estimated to be $57.6 \pm 0.7 \mathrm{~g} / 100 \mathrm{~g}$. However, the assumptions made by this method are quite rough as the relative content of nitrogen varies between amino acids and amino acid composition varies between food proteins [51]. In addition, the presence of non-protein nitrogen compounds such as nitrates, ammonia, urea, nucleic acids, free amino acids, chlorophylls, and alkaloids can lead to overestimations of the protein content.

The analysis of the amino acid profile by HPLC-IC permits to estimate the protein content of codfish frames. The total sum of amino acids as determined by this method gives an intermediate value for the protein content of $46.5 \pm 0.9 \mathrm{~g} / 100 \mathrm{~g}$. Nonetheless, this method assumes that no free amino acids are present in the raw material and relies on a protein hydrolysis step prior to analysis, which in this work was carried out in $4.2 \mathrm{M}$ $\mathrm{NaOH}$ at $110^{\circ} \mathrm{C}$ for $24 \mathrm{~h}$. Harsh conditions efficiently hydrolyze most of the peptide bonds, but some amino acids can be further destroyed, leading to an underestimation of the protein content [50].

The amino acid profile allows to calculate a corrected NPCF by considering the actual nitrogen content of each amino acid. Following the National Renewable Energy 
Laboratory (NREL) protocols [44], the specific NPCF for codfish frames was calculated to be $5.1 \pm 0.3$. This value is lower than the typical factor of 6.25 and corresponds to a higher average presence of nitrogen in the codfish frames proteins, of $19.6 \%$, which is closer to the average value for collagen containing meat of $18 \%$ [52]. Based on this corrected NPCF and the analysis of nitrogen, the protein content of codfish frames was determined to be $47.0 \pm 0.9 \mathrm{~g} / 100 \mathrm{~g}$. Though all the protein analysis methods used in this work have their drawbacks, we adopted the last value as the actual protein content for subsequent calculations. This value is close to the one obtained by the sum of amino acids, demonstrating low degradation during the alkaline hydrolysis step.

The protein content of codfish frames as determined by the corrected NPCF is higher than the value reported by Toppe et al. [2]. However, in their case, all possible adhered muscle was removed by further processing the raw material in boiling water, whereas the codfish frames used in this work were not boiled. This might also explain the lower ash content observed in this work compared to them. The low lipids content of codfish frames agrees with the previously reported values [2], which are characteristic of lean fish that store fat in their liver. Carbohydrate content of codfish frames was found to be very low, as expected.

Regarding the relative amino acid composition of codfish frames (Table 1), we can see high contents of glycine, alanine, and proline, as well as hydroxyproline (8.8\%) that is almost exclusively found in collagen. The hydroxyproline content in codfish frames protein is higher than that previously reported for Salmo salar skin (5.68 g per $100 \mathrm{~g}$ of protein) but similar to that for bovine achilles tendon and femur (respectively, 8.15 and $10.79 \mathrm{~g}$ per $100 \mathrm{~g}$ of protein) [53]. According to Equation (1), collagen content of codfish frames can be estimated from the hydroxyproline content. The value obtained for the codfish frames studied in this work was $30.6 \pm 0.8 \mathrm{~g}$ of collagen per $100 \mathrm{~g}$ of codfish frames, which accounts for roughly $2 / 3$ of the total proteins present in the original material. This value is comparable to those found in codfish skin [54,55].

Mineral profile is similar to that reported by Toppe et al. [2]. Calcium and phosphorous are the major mineral compounds, followed by sodium and magnesium. Minor elements are zinc and iron. The $\mathrm{Ca} / \mathrm{P}$ ratio, which can be used as an indication of the presence and purity of hydroxyapatite, was 1.801. This value is higher than the stoichiometric 1.667, although it lies within the acceptable ranges for hydroxyapatite [56]. The presence of common heavy metals was also monitored. Most of them were absent or present within legal limits, which opens the utilization of codfish frames derived materials in human food and pharmaceutical applications.

\subsection{Extraction Yield and Extract Composition}

SBW extracts obtained at target temperatures of $90,140,190$ and $250{ }^{\circ} \mathrm{C}$ were lyophilized to calculate the extraction yield during the SBW experiments. The protein content of the samples was calculated from the respective nitrogen content and using the previous corrected NPCF of 5.1. The results obtained are shown in Figure 1.

From this figure, we can see that the extraction yield reached $53.9 \mathrm{~g} / 100 \mathrm{~g}$, with a nearly total protein recovery. The mode of operation with several heating ramps allows to collect samples at different target temperatures, giving an idea of the extraction yield and the extract characteristics at each temperature in order to further explore specific extraction conditions. An additional SBW run was tested using a single heating ramp from ambient temperature to $250^{\circ} \mathrm{C}$, and then maintaining this temperature constant for a further $50 \mathrm{~min}$. This method was faster and resulted in a higher extraction yield $(57.7 \mathrm{~g} / 100 \mathrm{~g})$ in $4 \mathrm{~h}$ of assay with a protein recovery of almost $100 \%$. 


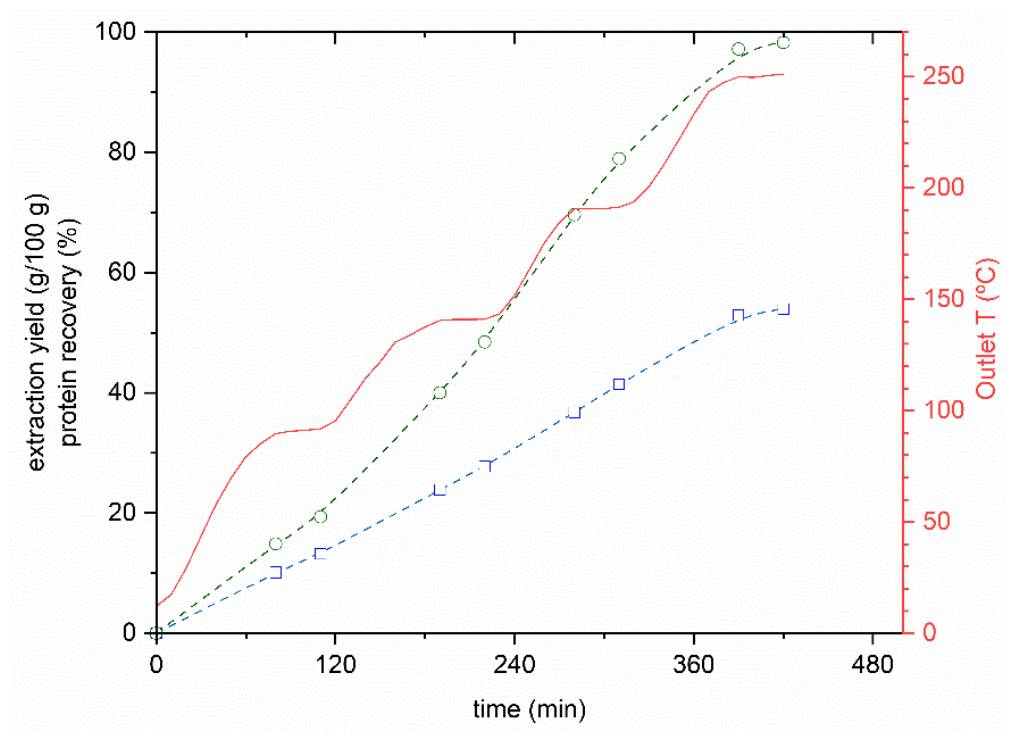

Figure 1. Temperature profile (solid line), extraction yield $(\square)$ and protein recovery $(\bigcirc)$ during subcritical water hydrolysis of codfish frames at target temperatures of 90, 140, 190, and $250{ }^{\circ} \mathrm{C}$. Dotted lines are guidelines connecting data points.

Table 2 summarizes the results obtained at each of the target temperatures and with a single heating ramp. ca. 95\% of the initial mass of codfish frames processed by SBW was recovered in the end of the assays, either as extract or final residue. The undetected material may be organic compounds decomposed to volatile species due to the high temperature conditions involved.

Table 2. Extraction yield and composition of extracts and final residue obtained from subcritical water hydrolysis of codfish frames.

\begin{tabular}{|c|c|c|c|}
\hline Temperature $\left({ }^{\circ} \mathrm{C}\right)$ & $\begin{array}{l}\text { Extraction Yield } \\
(\mathrm{g} / 100 \mathrm{~g})\end{array}$ & Protein Content (wt \%) & Ash Content (wt \%) \\
\hline \multicolumn{4}{|c|}{ Mode of operation: heating ramps $\left(90,140,190\right.$ and $\left.250^{\circ} \mathrm{C}\right)$} \\
\hline $25-90$ & 13.2 & 81.6 & 15.4 \\
\hline $90-140$ & 27.7 & 93.6 & 2.7 \\
\hline $140-190$ & 41.4 & 95.0 & 2.5 \\
\hline $190-250$ & 53.9 & 84.4 & 13.2 \\
\hline Residue & & 0.1 & 99.6 \\
\hline \multicolumn{4}{|c|}{ Mode of operation: single heating step (up to $250^{\circ} \mathrm{C}$ ) } \\
\hline $25-250$ & 57.7 & 84.4 & 10.1 \\
\hline Residue & & n.d. & 99.8 \\
\hline
\end{tabular}

Regarding the composition of the SBW extracts, and as expected, protein was the major compound in all the SBW extracts, followed by mineral compounds. Lipid and carbohydrate compounds were found in minor quantities, closing the mass balance.

The residue left in the reactor after the SBW assays was almost completely composed of mineralized compounds, with protein present in traces or not detected, such as carbohydrates and lipids. These results demonstrate the deproteinization ability of the SBW method developed in this work and show its potential to produce pure HAp from codfish frames.

The amino acid profile of the SBW extracts obtained at different target temperatures was also analyzed by HPLC-IC method. First, extract samples were directly analyzed, omitting the alkaline digestion step to determine the presence of free amino acids. Then, the extracts were submitted to alkaline hydrolysis and subsequently analyzed for the total amino acid profile of protein fragments and peptides. As it can be observed from Table 3, free amino acids are present in low quantities at $90{ }^{\circ} \mathrm{C}$, the lowest temperature studied 
in this work, accounting for approximately $2.6 \%$ of the total amino acids detected in the sample. When extraction temperature increases, the ratio of free to total amino acids increases up to 7.3 and $7.7 \%$ at 140 and $190{ }^{\circ} \mathrm{C}$, respectively. Production of free amino acids reaches its maximum at $250{ }^{\circ} \mathrm{C}$, the highest temperature studied in this work. At this temperature, $22 \%$ of the detected amino acids were in free form according to the analysis of the amino acid profile. Similar results have been reported in the literature, since temperatures in the range $220-260{ }^{\circ} \mathrm{C}$ have been reported as the optimal for amino acid production by SBW process, depending on the raw material and mode of operation [29-40]. In a previous work with sardine waste from fish canning, the highest yield of free amino acids was found at $140{ }^{\circ} \mathrm{C}$ and amino acid production decreased at higher temperatures due to thermal decomposition into organic acids and volatile carbon [40]. From these results, it is obvious that the amino acid profile and the nature of the proteins present in the raw material, together with the operating temperature and residence time (i.e., the severity of the SBW treatment) exerts an important influence in the production of free amino acids.

Table 3. Amino acid profile of extracts obtained from subcritical water hydrolysis of codfish frames.

\begin{tabular}{|c|c|c|c|c|c|c|c|c|}
\hline & \multicolumn{8}{|c|}{ Amino Acid Profile (mg/g) } \\
\hline & \multicolumn{2}{|c|}{$90^{\circ} \mathrm{C}$} & \multicolumn{2}{|c|}{$140^{\circ} \mathrm{C}$} & \multicolumn{2}{|c|}{$190^{\circ} \mathrm{C}$} & \multicolumn{2}{|c|}{$250^{\circ} \mathrm{C}$} \\
\hline & Free & Total & Free & Total & Free & Total & Free & Total \\
\hline Arginine (Arg) & 5.22 & 47.14 & 16.67 & 56.85 & 14.06 & 39.74 & 27.83 & 54.75 \\
\hline Lysine (Lys) & 0.19 & 35.01 & 3.77 & 36.50 & 1.15 & 32.53 & 4.91 & 24.54 \\
\hline Alanine (Ala) & 5.40 & 155.56 & 3.31 & 135.56 & 3.07 & 132.41 & 30.67 & 111.41 \\
\hline Threonine (Thr) & n.d. & 4.13 & 2.52 & 4.56 & 1.00 & 9.97 & n.d. & 24.42 \\
\hline Glycine (Gly) & 1.39 & 116.66 & 3.31 & 107.28 & 6.30 & 118.49 & 33.35 & 145.04 \\
\hline Valine (Val) & 0.32 & 10.30 & 2.45 & 15.64 & 2.26 & 10.24 & 7.02 & 3.17 \\
\hline Serine (Ser) & n.d. & 44.93 & 0.40 & 52.48 & 0.54 & 76.51 & n.d. & 81.08 \\
\hline Proline (Pro) & 1.75 & 90.20 & 3.95 & 92.88 & 6.09 & 116.63 & 9.71 & 88.11 \\
\hline $\begin{array}{c}\text { Hydroxyproline } \\
\text { (Hyp) }\end{array}$ & 1.59 & 88.91 & 3.55 & 81.61 & 5.56 & 86.12 & 12.07 & 100.27 \\
\hline Leucine (Leu) & 0.18 & 23.78 & 0.89 & 18.66 & 0.60 & 4.29 & 6.53 & 24.52 \\
\hline Isoleucine (Ile) & 0.42 & 20.52 & 2.76 & 30.82 & 3.55 & 59.83 & 14.61 & 37.74 \\
\hline Methionine (Met) & 0.29 & 6.05 & 2.84 & 5.60 & 0.68 & 24.20 & 4.13 & 7.77 \\
\hline Histidine (His) & 0.09 & 8.44 & 4.62 & 4.25 & 0.62 & 5.22 & 1.40 & 4.39 \\
\hline Phenylalanine (Phe) & 0.62 & 5.02 & 4.25 & 18.79 & 3.07 & 4.05 & 3.82 & 3.15 \\
\hline Glutamic acid (Glu) & 0.40 & 30.46 & n.d. & 98.33 & n.d. & 1.10 & 0.00 & 22.69 \\
\hline Aspartic acid (Asp) & 0.32 & 26.63 & 1.86 & 18.39 & 4.45 & 5.31 & 4.45 & 12.67 \\
\hline Cysteine (Cys) & n.d. & n.d. & n.d. & 0.86 & n.d. & 0.70 & n.d. & 0.98 \\
\hline Tyrosine (Tyr) & 0.49 & 5.26 & 3.09 & 42.77 & 3.51 & 6.31 & 5.16 & 8.70 \\
\hline Total & 18.67 & 719.00 & 60.24 & 821.83 & 56.50 & 733.65 & 165.67 & 755.40 \\
\hline Free/total ratio & \multicolumn{2}{|c|}{0.026} & \multicolumn{2}{|c|}{0.073} & \multicolumn{2}{|c|}{0.077} & \multicolumn{2}{|c|}{0.22} \\
\hline
\end{tabular}

Experimental uncertainty $(\mathrm{u})= \pm 0.1 \mathrm{mg} / \mathrm{g}$ extract; n.d.: not detected.

In relative terms, there are not many significant changes in the amino acid profiles of the SBW extracts obtained at the different temperatures studied in this work, and these profiles are also similar to that of the original codfish frames. These results indicate a low amino acid selectivity of the SBW process, which was already observed in a previous work with sardine waste [40]. The predominance of glycine, alanine and proline continues, although alanine was the most abundant amino acid instead of glycine at 90, 140 and $190^{\circ} \mathrm{C}$. At $250^{\circ} \mathrm{C}$, glycine increased again, likely due to amino acid transformation during SBW process [57].

\subsection{Mineral Profile of Extracts}

Major mineral compounds of extracts are shown in Table 4, together with the mineral profile of the raw material and the minerals found in the residue left after SBW process. Mineral recovery was calculated for each species, based on the mineral composition of the extracts and residue left after extraction, weighted by the extraction yield at each 
temperature and the final yield of mineralized residue. For each mineral compound, it can be observed that the calculated values are close to those obtained in the determination of the mineral profile of the raw material, validating the results obtained.

Table 4. Major minerals and toxic and heavy metals found in extracts obtained from subcritical water hydrolysis of codfish frames.

\begin{tabular}{|c|c|c|c|c|c|c|c|}
\hline Mineral & $\begin{array}{l}\text { Codfish } \\
\text { Frames }\end{array}$ & $\begin{array}{c}\text { Extract } \\
90^{\circ} \mathrm{C}\end{array}$ & $\begin{array}{l}\text { Extract } \\
140{ }^{\circ} \mathrm{C}\end{array}$ & $\begin{array}{l}\text { Extract } \\
190{ }^{\circ} \mathrm{C}\end{array}$ & $\begin{array}{l}\text { Extract } \\
250{ }^{\circ} \mathrm{C}\end{array}$ & $\begin{array}{c}\text { Residue } \\
\text { after SBW }\end{array}$ & $\begin{array}{l}\text { Recovery } \\
\text { mg/g Feed }\end{array}$ \\
\hline \multicolumn{8}{|c|}{ Major mineral compounds (mg/g) } \\
\hline $\mathrm{Ca}$ & 143 & 2.58 & 0.38 & 0.27 & 0.51 & 410 & 147.2 \\
\hline $\mathrm{Na}$ & 5.3 & 17.70 & 0.78 & 0.82 & 0.59 & 2.1 & 3.9 \\
\hline $\mathrm{P}$ & 69.4 & 1.54 & 1.76 & 1.56 & 0.45 & 221 & 80.5 \\
\hline $\mathrm{Mg}$ & 2.43 & 0.40 & 0.12 & 1.10 & 0.21 & 8.5 & 3.7 \\
\hline $\mathrm{Zn}$ & 0.0351 & 0.061 & 0.008 & 0.052 & 0.025 & 0.03 & 0.057 \\
\hline $\mathrm{Fe}$ & 0.0073 & 0.005 & 0.001 & 0.003 & 0.002 & 0.008 & 0.006 \\
\hline \multicolumn{8}{|c|}{ Toxic and heavy metals (ppm) } \\
\hline $\mathrm{Cr}$ & n.d. & n.d. & n.d. & n.d. & n.d. & n.d. & \\
\hline As & 0.4 & 0.09 & 0.09 & 0.28 & n.d. & 0.79 & 0.440 \\
\hline $\mathrm{Cd}$ & n.d. & n.d. & n.d. & n.d. & n.d. & n.d. & \\
\hline $\mathrm{Hg}$ & 0.1 & n.d. & n.d. & n.d. & n.d. & n.d. & \\
\hline $\mathrm{Pb}$ & 0.3 & 0.28 & 0.28 & 0.21 & 0.1 & 0.4 & 0.409 \\
\hline
\end{tabular}

From Table 4, it can be seen that $\mathrm{Ca}, \mathrm{Na}$ and $\mathrm{P}$ are the most abundant of the analyzed mineral compounds in the codfish extracts. Na is present in significantly higher quantities in the first extract, indicating that the more soluble sodium salts were extracted in the earlier stages of the SBW process at temperatures as low as $90^{\circ} \mathrm{C}$. On the other hand, $\mathrm{Ca}, \mathrm{P}$ and $\mathrm{Mg}$ accumulated in the residue, meaning that hydroxyapatite and other mineralized structures were not significantly affected by SBW process up to $250{ }^{\circ} \mathrm{C}$. Similar results were also found in a previous work dealing with SBW of sardine waste [40]. Heavy metals and toxic elements were absent or present in quantities within legal limits [58], which opens the utilization of SBW extracts from codfish frames in human food and pharmaceutical applications.

\subsection{Molecular Weight Distribution of SBW Extracts}

\subsubsection{SDS-PAGE of Codfish Extracts}

Figure 2 shows the electrophoretic profiles of codfish extracts obtained after SBW process. The $7.5 \%$ precast gel depicted in the image on the left achieved better separation of the high-molecular weight bands. In the samples obtained at $90{ }^{\circ} \mathrm{C}$, intense bands can be observed at high molecular weight $(>245 \mathrm{kDa})$. These bands, which might correspond to non-hydrolyzed collagen components ( $\beta$ and $\gamma$ chains), are less visible at $140{ }^{\circ} \mathrm{C}$ and not present at 190 and $250{ }^{\circ} \mathrm{C}$, indicating the effectiveness of temperature in the hydrolysis of collagen from codfish frames.

Comparing the SDS-PAGE results obtained in this work with the electrophoretic patterns of Type I and II collagens reported in the literature for other fish species [39,58-60], the characteristic double bands found at 125 and $110 \mathrm{kDa}$, corresponding to $\alpha 1$ and $\alpha 2$ chains, are noticeably absent even at the lowest temperature assayed $\left(90^{\circ} \mathrm{C}\right)$. Instead, several bands that might correspond to degradation products of these $\alpha$ chains can be observed below $63 \mathrm{kDa}$ (Figure 2, right). Again, these bands become less intense at higher hydrolysis temperatures. The absence of these bands in the hydrolysates has been reported in the literature for collagen hydrolysates obtained by enzymatic and other alternative methods, including SBW [39,59-61]. In the case of the extracts obtained at 190 and $250{ }^{\circ} \mathrm{C}$, low molecular weight bands were observed near the bottom of the gel indicating the presence of the low mass proteins in the hydrolysate. The molecular weight of these bands was 
graphically determined and estimated to be less than $6 \mathrm{kDa}$, which is also in concordance with results from SBW of fish proteins available in the literature $[35,60,61]$.
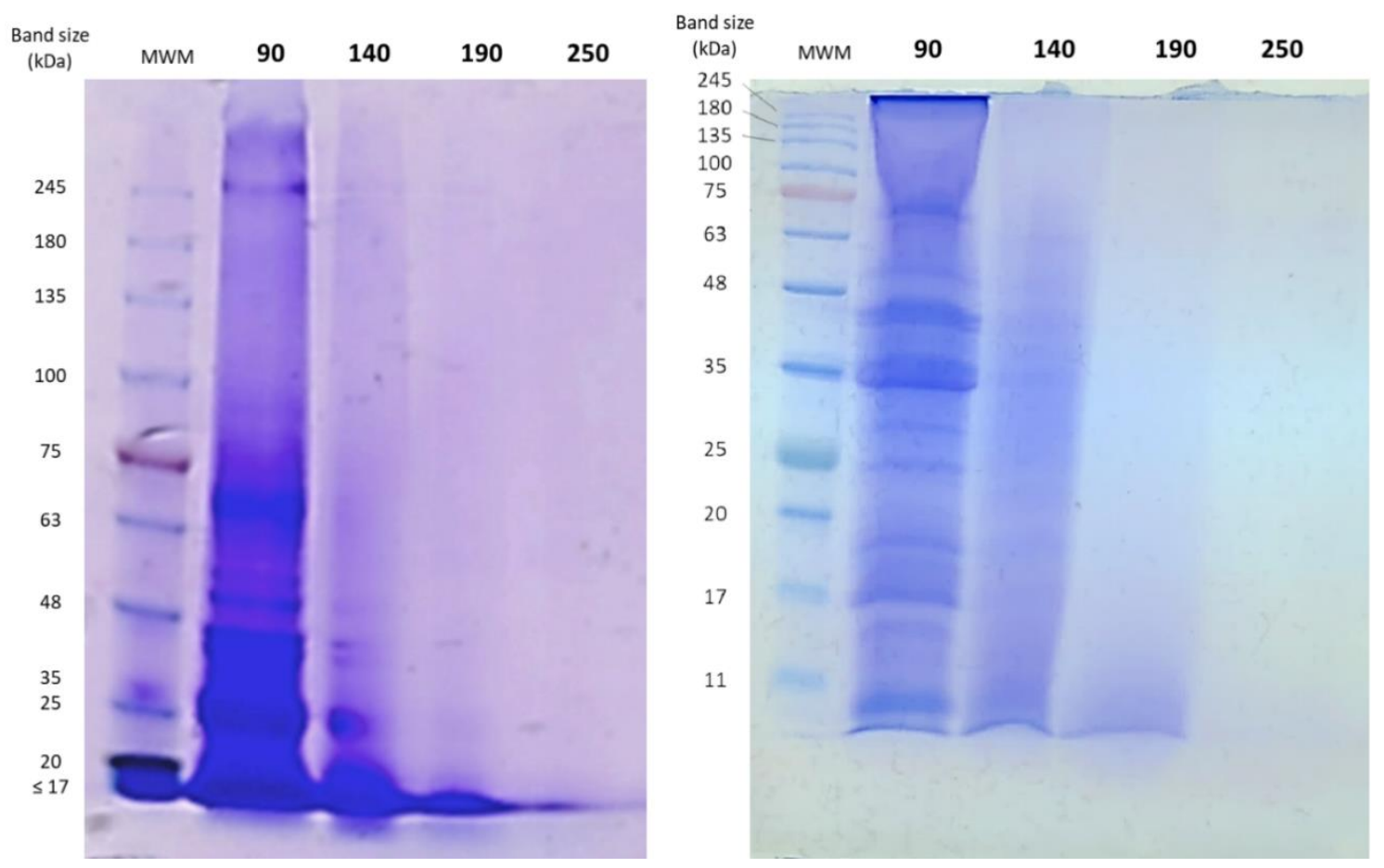

Figure 2. Polyacrylamide gels obtained in the SDS-PAGE of codfish SBW extracts at different temperatures (90, 140, 190, and $\left.250{ }^{\circ} \mathrm{C}\right)$. Left: $7.5 \%$ precast acrylamide gel; right: handcast acrylamide gel (4.5\% stacking and 15\% resolving gel). MWM: molecular-weight marker.

\subsubsection{SEC-GPC of SBW Extracts}

The molecular weight distributions of the SBW extracts are shown as SEC-GPC curves in Supplementary Figure S1. The retention times of the molecular mass standards were $5.48 \mathrm{~min}$ for bovine Thyroglobulin $(670 \mathrm{kDa}), 6.82 \mathrm{~min}$ for $\gamma$-Globulin from bovine blood (150 kDa), $8.53 \mathrm{~min}$ for Albumin for chicken egg grade VI (44.3 kDa), and $9.70 \mathrm{~min}$ for Ribonuclease A type I-A from bovine pancreas $(13.7 \mathrm{kDa})$. The data collected from the SEC-GPC chromatograms is presented in Table 5.

The SEC-GPC chromatogram of the SBW extract obtained at $90^{\circ} \mathrm{C}$ showed several peaks at 4.05, 5.92, 7.95, and $9.65 \mathrm{~min}$ (Figure S1a), corresponding to high and medium molecular-weight peptides (estimated $\mathrm{M}_{\mathrm{w}}$ of $1451,361,82.3$, and $20.8 \mathrm{kDa}$, respectively) that might have been partially hydrolyzed and extracted in the subcritical water treatment at mild temperatures. Three more peaks are present at 11.20, 11.73 and $12.90 \mathrm{~min}$, with estimated $\mathrm{M}_{\mathrm{W}}$ of 5.6, 2.6 and $1.1 \mathrm{kDa}$, respectively. The highest peak observed in the SBW extract obtained at $90^{\circ} \mathrm{C}$ presented a retention time of $12.92 \mathrm{~min}(1.1 \mathrm{kDa})$.

In the SBW extract obtained at $140{ }^{\circ} \mathrm{C}$ (Figure S1b), the first peak is observed at $\mathrm{RT}=9.35 \mathrm{~min}(87.7 \mathrm{kDa})$, indicating that most of the high molecular-weight compounds at this relatively higher temperature have been hydrolyzed into smaller peptides. The highest peak was observed at $11.25 \mathrm{~min}(5.7 \mathrm{kDa})$, and a lower peak was also observed at $12.9 \mathrm{~min}(0.9 \mathrm{kDa})$. In the SBW extracts obtained at 190 and $250{ }^{\circ} \mathrm{C}$ (Figure S1c,d), the highest intensity peaks were observed at $11.3 \mathrm{~min}$ ( 3.2 to $5.9 \mathrm{kDa}$ ); thus, the position of the highest peak in the SEC-GPC curves shifted to a longer retention time with increasing process temperature in SBW. Several small peaks were also observed at RT $>15 \mathrm{~min}$, likely corresponding to degradation products with $\mathrm{M}_{\mathrm{W}}<1 \mathrm{kDa}$. 
Table 5. Results obtained from the SEC-GPC chromatograms of the SBW extracts.

\begin{tabular}{|c|c|c|c|c|c|c|}
\hline Peak No. & $\begin{array}{l}\text { Max. RT } \\
\text { (min) }\end{array}$ & $\mathrm{M}_{\mathrm{p}}(\mathrm{kDa})$ & $M_{n}(k D a)$ & $\mathbf{M}_{\mathrm{w}}(\mathrm{kDa})$ & PD * & Area \% \\
\hline \multicolumn{7}{|c|}{ Codfish extract at $90^{\circ} \mathrm{C}$} \\
\hline 2 & 5.92 & 331.7 & 329.7 & 360.9 & 1.0946 & 3.21 \\
\hline 3 & 7.95 & 62.5 & 67.4 & 82.3 & 1.2220 & 6.32 \\
\hline 4 & 9.65 & 15.5 & 18.8 & 20.8 & 1.1078 & 7.54 \\
\hline 5 & 11.2 & 4.33 & 5.09 & 5.61 & 1.1010 & 25.68 \\
\hline 6 & 11.73 & 2.80 & 2.49 & 2.57 & 1.0293 & 17.14 \\
\hline 7 & 12.90 & 1.07 & 0.96 & 1.08 & 1.1305 & 38.99 \\
\hline \multicolumn{7}{|c|}{ Codfish extract at $140^{\circ} \mathrm{C}$} \\
\hline 1 & 9.35 & 19.8 & 36.1 & 87.7 & 2.4287 & 36.36 \\
\hline 2 & 11.25 & 4.16 & 4.08 & 5.69 & 1.3941 & 52.38 \\
\hline 3 & 12.92 & 1.06 & 0.77 & 0.92 & 1.1961 & 11.04 \\
\hline \multicolumn{7}{|c|}{ Codfish extract at $190^{\circ} \mathrm{C}$} \\
\hline 1 & 11.3 & 3.99 & 0.98 & 5.93 & 6.0706 & 96.12 \\
\hline \multicolumn{7}{|c|}{ Codfish extract at $250^{\circ} \mathrm{C}$} \\
\hline 1 & 11.28 & 4.05 & 2.20 & 3.21 & 1.4588 & 65.59 \\
\hline 2 & 14.02 & 0.43 & 0.16 & 0.30 & 1.8868 & 23.55 \\
\hline
\end{tabular}

As a general trend, the SEC-GPC chromatograms showed that high and medium molecular-weight peptides $(20-1500 \mathrm{kDa})$ were extracted at the lowest temperature $\left(90^{\circ} \mathrm{C}\right)$. Increasing SBW temperature up to $140{ }^{\circ} \mathrm{C}$ promoted the hydrolysis of larger proteins and peptides, and low molecular-weight products $\left(\mathrm{M}_{\mathrm{W}}\right.$ around $\left.4-6 \mathrm{kDa}\right)$ appeared in the extract. Further temperature increments up to 190 and $250{ }^{\circ} \mathrm{C}$ enhanced the hydrolysis process, and only small molecules with $\mathrm{M}_{\mathrm{w}}<4 \mathrm{kDa}$ were obtained, some of them being smaller than $1 \mathrm{kDa}$. Similar results have been reported by other authors. Koomyart et al. [62] treated semidried Isada krill with subcritical water at $100-240{ }^{\circ} \mathrm{C}$ interval and used SEC chromatography to qualitatively analyze the molecular mass distribution of their extracts. They observed that SBW extracts collected at $100-140{ }^{\circ} \mathrm{C}$ had several peaks corresponding to molecular masses higher than $1000 \mathrm{kDa}$, while at temperatures higher than $160^{\circ} \mathrm{C}$, a greater number of lower-molecular mass compounds $(<10 \mathrm{kDa})$ were detected. Ueno et al. [37] when degrading fish gelatin with subcritical water at temperatures between 160 and $240{ }^{\circ} \mathrm{C}$ have reported an increase in the number of the peptides formed with increasing the temperature, by SEC-GPC analysis of the respective extracts. The retention time of the highest peaks observed for extracts obtained at $160-200{ }^{\circ} \mathrm{C}$ were ca. $4.5 \mathrm{~min}(303 \mathrm{kDa})$ and the retention times for the $220-240{ }^{\circ} \mathrm{C}$ extracts were ca. $5.0 \mathrm{~min}(235 \mathrm{kDa})$. Collagen isolated from Mackerel bone and skin, processed with SBW at $200-250{ }^{\circ} \mathrm{C}$ [39], resulted in the production of smaller molecular-weight compounds, ranging from 790 to $1400 \mathrm{Da}$, with the application of high temperatures.

\subsection{Anti-Inflammatory Potential of Codfish SBW Extracts on Caco-2 Cells}

Chronic inflammation is related to the development and progression of many chronic diseases such as autoimmune diseases, metabolic disorders, fibrosis, and cancer. Nutrition patterns influence the inflammation level, and any healthy diet should take into consideration the impact on systemic inflammation [63]. Thus, the obtained extracts were evaluated as potential anti-inflammatory food ingredients.

Codfish SBW extracts were firstly tested for their cytotoxicity using confluent and undifferentiated Caco-2 cells as a model for crypt enterocytes [47]. Results obtained after $24 \mathrm{~h}$ of culture conclude that codfish SBW extracts did not show cytotoxicity to Caco-2 cell line in the range of tested concentrations (EC50>50 mg/mL). To determine the anti-inflammatory potential of codfish SBW extracts, Caco-2 cells were incubated with the extracts at $25 \mathrm{mg} / \mathrm{mL}$ and with a cocktail of cytokines (IL- $1 \beta$, TNF- $\alpha$ and LPS). The expression of the interleukin-8 (IL-8), one of the major mediators of the inflammatory 
response, in cell culture supernatants was quantified through ELISA and is shown in Figure 3. According to Matias et al. [64], the secretion of IL8 is correlated to the modulation NF- $\kappa B$ pathway. When the transcription factor NF- $\kappa B$ is activated, it migrates to the nucleus and promotes the transcription of proinflammatory genes.

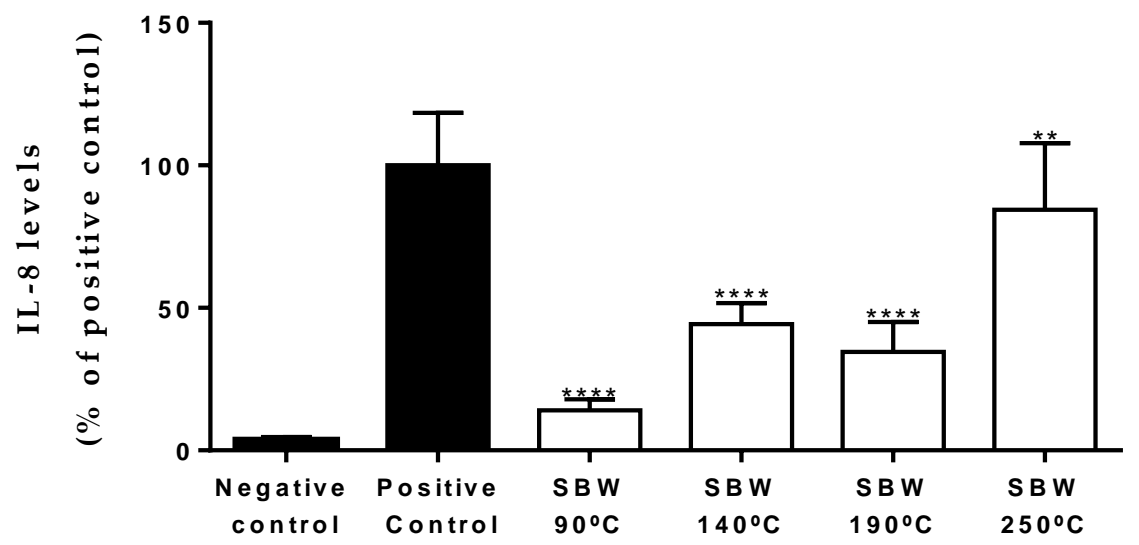

Figure 3. IL-8 produced by Caco-2 cells treated with cod fish SWH extracts at different temperatures $\left(90,140,190\right.$, and $\left.250^{\circ} \mathrm{C}\right)$ and using a cocktail of cytokines (IL-1 $\beta$, TNF $\alpha$ and LPS) to mimic inflammation. The results are expressed as mean \% positive control $\pm \mathrm{SD}, n=5 .{ }^{* *} p<0.01,{ }^{* * * *} p<0.0001$, significantly different when compared to positive control, using $t$-test $(p<0.05)$.

Results show that all codfish SBW extracts lead to a decrease in IL- 8 release, comparing with positive control, which means that NF-kB pathway is inhibited. SBW $90{ }^{\circ} \mathrm{C}$ is the extract that shows higher decrease of inflammation, (14.1 $\pm 0.7 \%$, a reduction of $85.9 \%$ comparing to the positive control; $\left.{ }^{* * *} p<0.0001\right)$. SBW $140^{\circ} \mathrm{C}$ and SBW $190^{\circ} \mathrm{C}$ exhibit an IL-8 reduction of 55.7\% (44.3 $\pm 1.4 ;{ }^{* * * *} p<0.0001$ vs. positive control) SBW 65.5\% (34.5 $\pm 2.1 \%{ }^{* * * *} p<0.0001$ vs. positive control), respectively. On the other hand, SBW $250^{\circ} \mathrm{C}$ is the extract that presents the lowest anti-inflammatory potential, with a reduction of $15.5 \%$ in the release of IL-8 $(84.5 \pm 4.9 \%$; ** $p<0.01$ vs. positive control). These results are in accordance with previously published works regarding the anti-inflammatory potential of low molecular weight fish peptides $[65,66]$, and suggest that anti-inflammatory peptides are produced and extracted at low temperatures; whereas at higher temperatures up to $250{ }^{\circ} \mathrm{C}$, the degradation of these compounds into smaller peptides, free amino acids and other substances without anti-inflammatory activity occurs. A similar behavior has been observed in the production of antihypertensive peptides from fish gelatin using SBW [37].

\subsection{Hydroxyapatite Isolation and Characterization}

As described in Section 2, the deproteinized residue that remained after the SBW assay, together with the residues obtained after direct heating or alkaline digestion of the codfish frames, were analyzed by FT-IR spectroscopy, X-ray diffraction, and FEG-SEM microscopy.

\subsubsection{FT-IR Characterization}

FT-IR spectroscopy provides information about the vibrational behavior of inter and intramolecular bonds; thus, it can be used for structural investigation of the extracellular matrix of codfish frames. Figure 4 shows the FT-IR spectra of untreated codfish frames, SBW extracts obtained at different temperatures, and the residues obtained after SBW process, direct heating at $550{ }^{\circ} \mathrm{C}$, and alkaline extraction by $4.2 \mathrm{M} \mathrm{NaOH}$ solution at $110{ }^{\circ} \mathrm{C}$. The spectrum of pure calcium phosphate hydroxide obtained from the NIST database [48] is also shown for comparison. From this figure, important differences can be observed between the spectra of the raw codfish frames and the residues from SBW, direct heating, and alkaline extraction, revealing that the bone chemical structure has significantly changed during treatment. Spectra of the residues are similar to that of the pure HAp standard, 
most notoriously for the SBW residue. These results suggest that the residue obtained after SBW process is mostly composed of highly pure HAp.

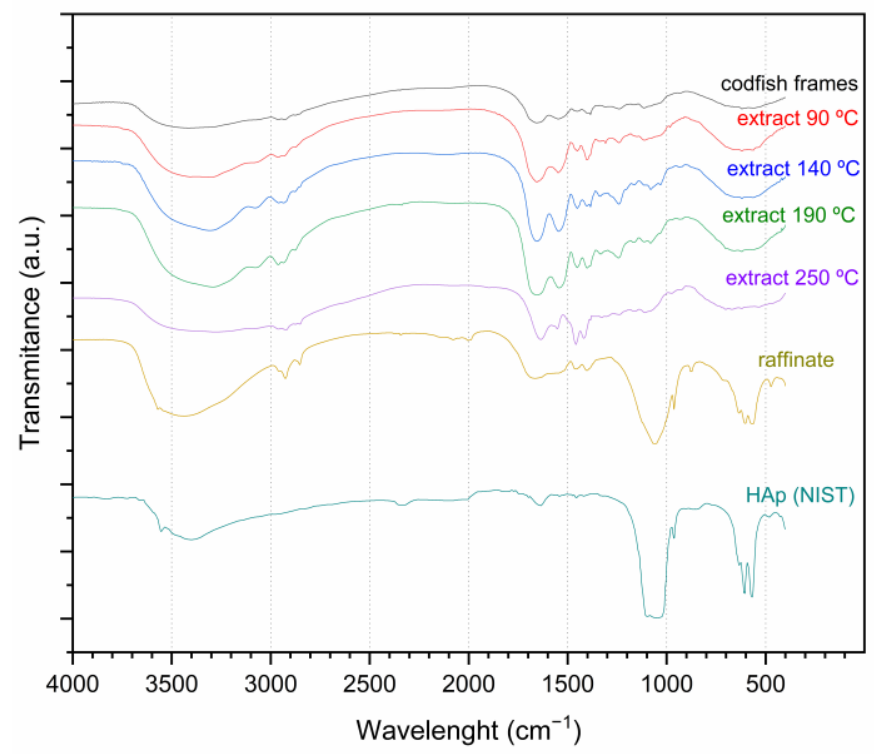

Figure 4. FT-IR spectra of powdered codfish frames, extracts obtained from subcritical water hydrolysis at different temperatures and the residues left after SBW process, thermal decomposition at $550{ }^{\circ} \mathrm{C}$, and alkaline hydrolysis of codfish frames. Spectra of calcium phosphate hydroxide taken from NIST database [48].

Characteristic bands of HAp, related to $\mathrm{OH}$ stretching $\left(\right.$ at $3569 \mathrm{~cm}^{-1}$ ) and liberation $\left(635 \mathrm{~cm}^{-1}\right.$ ), as well as intense phosphate contours (from 500 to $1100 \mathrm{~cm}^{-1}$ ) can be observed in all the residues and pure HAp standard. These bands are not so clear in the original codfish frames due to the cross-linked structure of codfish frames and the presence of collagen proteins that limited vibrational behavior.

The SBW extracts obtained at different temperatures were also submitted to FT-IR spectroscopy since this technique may provide useful information on the protein structure through the analysis of the three main amide regions: I, II, and III. Amide I bands have been reported at 1622, 1636 and $1685 \mathrm{~cm}^{-1}$ in collagen/hydroxyapatite composites [67]. As it can be seen in Figure 4, amide I bands appear at these wavelengths in the original codfish frames as well as in the SBW extracts. According to Chang and Tanaka [67], Amide II major band appears at $1559 \mathrm{~cm}^{-1}$, and some minor bands at 1521, 1533 and $1543 \mathrm{~cm}^{-1}$. Figure 4 shows Amide II peaks in the original codfish frames as well as in the SBW extracts. Characteristic peaks of Amide III band appear at 1231, 1248, and $1281 \mathrm{~cm}^{-1}$ [67] and are typically of low intensity. In codfish frames, we observed some small peaks displaced to 1235,1269 , and $1295 \mathrm{~cm}^{-1}$. A similar displacement of the Amide III region was also observed by Barakat et al. [41] and was attributed to changes in the degree of cross-linking between the natural bone and the collagen/hydroxyapatite composite used in that study. Comparing the FT-IR spectra of the SBW extracts with that of the original cod fish frames, we can see that the chemical structure of the proteins was not substantially modified after SBW process. Peaks of the Amide I, II and III regions appear with higher intensity in the SBW extracts, which is likely due to the higher protein purity in the extracts and to the loss of the cross-linked structure of the bone that limited the vibration of the functional groups of the peptide linkage. Other noticeable peaks that can be taken into consideration appeared at 1398 and $1452 \mathrm{~cm}^{-1}$. These new peaks present higher intensity at $250{ }^{\circ} \mathrm{C}$, contrary to the peaks from Amide I and II regions, which gain in intensity from 90 to $190^{\circ} \mathrm{C}$ and then decrease at $250{ }^{\circ} \mathrm{C}$. Since Amide I and II bands are related to the stretching and bending of the functional groups of the peptide linkage, their lower intensity at $250{ }^{\circ} \mathrm{C}$ suggest that protein hydrolysis is widely extended, as it has been confirmed by the high 
concentration of free amino acids at this temperature, as well as the results from SDS-PAGE and SEC-GPC analysis.

From Figure 4, it can be observed that both the Amide I, II and III bands and the new peaks observed in the SBW extracts are absent in the spectra of the codfish residues, confirming the ability of the SBW treatment for the protein removal and its equivalence to conventional HAp production methods such as thermal decomposition and alkaline digestion. Moreover, the similarity of the FT-IR spectrum of the SBW residue with that of the HAp standard suggest a high purity and crystallinity of the obtained HAp, which were further investigated by X-ray diffraction.

\subsubsection{X-ray Diffraction Profiles}

X-ray diffraction (XRD) was considered to evaluate the presence of crystalline HAp in the residue left after SBW process. The residues of thermal decomposition at $550{ }^{\circ} \mathrm{C}$ and alkaline hydrolysis of codfish frames were also submitted to XRD analysis. The obtained XRD spectra were compared with NIST data from HAp standard [49].

As shown in Figure 5, the spectrum of raw codfish frames only shows a small, diffuse peak around the $2 \theta=32^{\circ}$ region. Most likely, $X$-ray radiations have been dispersed by the fibrous collagen present in the bone extracellular matrix. On the other hand, the spectra of the samples obtained after thermal calcination and the SBW process are almost identical and show all the peaks corresponding to the standard HAp. Noteworthy, peaks were sharper in the spectra of the SBW treated codfish frames, suggesting that the SBW process can produce HAp with comparable or even higher crystallinity than the conventional thermal decomposition method. In the case of the spectrum of residue from alkaline hydrolysis, peaks were less defined and some of them could not be accurately identified, revealing that crystallinity and purity of HAp in this sample was not as high as in the others.

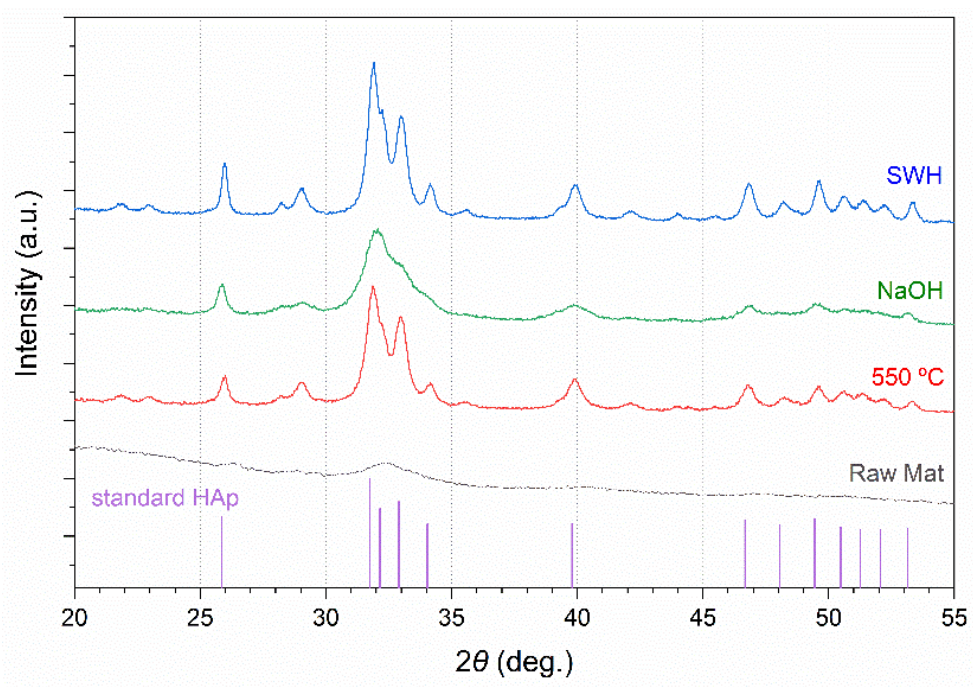

Figure 5. X-ray diffraction patterns of powdered codfish frames, and the residues left after SBW process, thermal decomposition at $550{ }^{\circ} \mathrm{C}$, and alkaline hydrolysis of codfish frames. Standard HAp data taken from NIST SRM 2910b [49].

Table 6 shows the planar spacings (estimated by Bragg's law) and the intensities at the strongest peaks in the XRD spectra. These results were compared with standard HAp data from NIST database and the relative errors were estimated at every plane. As it can be concluded from the total error values, the HAp obtained by the subcritical water process has planar spacings and intensities very close to the standard HAp, which indicates high crystallinity. Next is the product of thermal decomposition of codfish frames $\left(550^{\circ} \mathrm{C}, 4 \mathrm{~h}\right)$, followed by the residue obtained after alkaline digestion $\left(4.2 \mathrm{M} \mathrm{NaOH} 110^{\circ} \mathrm{C}, 24 \mathrm{~h}\right)$. Similar results were obtained by Barakat et al. [41] since their alkaline hydrothermal method also produced less crystalline HAp, compared to SBW and thermal decomposition processes. 
Table 6. Planar spacings and intensities obtained from X-ray diffraction of the residue left after SBW process, thermal decomposition at $550{ }^{\circ} \mathrm{C}$, and alkaline hydrolysis of codfish frames. Results are compared with standard HAp data from NIST SRM 2910b [63].

\begin{tabular}{|c|c|c|c|c|c|c|c|c|}
\hline \multirow[b]{2}{*}{$h k l$} & \multicolumn{4}{|c|}{ d-Value (nm) } & \multicolumn{4}{|c|}{ Intensity } \\
\hline & NIST & $\begin{array}{l}\text { Muffle } \\
550{ }^{\circ} \mathrm{C}\end{array}$ & $\begin{array}{l}\mathrm{NaOH} \\
110^{\circ} \mathrm{C}\end{array}$ & $\begin{array}{c}\text { SBW } \\
250^{\circ} \mathrm{C}\end{array}$ & NIST & $\begin{array}{l}\text { Muffle } \\
550^{\circ} \mathrm{C}\end{array}$ & $\begin{array}{l}\mathrm{NaOH} \\
110^{\circ} \mathrm{C}\end{array}$ & $\begin{array}{c}\text { SBW } \\
250{ }^{\circ} \mathrm{C}\end{array}$ \\
\hline 002 & 0.3444 & 0.3429 & 0.3445 & 0.3429 & 34 & 28 & 46.7 & 44 \\
\hline 210 & 0.3084 & 0.3076 & n.d. & 0.3079 & 15 & 28 & n.d. & 25 \\
\hline 211 & 0.2815 & 0.2808 & 0.2796 & 0.2805 & 100 & 100 & 100.0 & 100 \\
\hline 112 & 0.278 & 0.2714 & n.d. & 0.2776 & 48 & 76 & n.d. & 75 \\
\hline 300 & 0.272 & n.d. & n.d. & 0.2714 & 60 & n.d. & n.d. & 73 \\
\hline 202 & 0.2632 & 0.2627 & n.d. & 0.2633 & 21 & 26 & n.d. & 27 \\
\hline 310 & 0.2263 & 0.2259 & n.d. & 0.2264 & 22 & 33 & n.d. & 30 \\
\hline 222 & 0.1944 & 0.1940 & 0.2261 & 0.1940 & 28 & 26 & 30.1 & 28 \\
\hline 213 & 0.1842 & 0.1837 & n.d. & 0.1837 & 30 & 27 & n.d. & 27 \\
\hline 321 & 0.1807 & 0.1802 & 0.1938 & 0.1804 & 15 & 21 & 26.9 & 21 \\
\hline 004 & 0.1722 & 0.1719 & 0.1812 & 0.1717 & 13 & 16 & 20.5 & 20 \\
\hline $\begin{array}{l}\text { Total } \\
\text { Error }\end{array}$ & & 0.0459 & n.c. & 0.0230 & & 4.50 & n.c. & 3.43 \\
\hline
\end{tabular}

n.d.: not detected, n.c.: not calculated.

\subsubsection{FEG-SEM and EDS Characterization}

The morphology of the residue obtained after SBW process was checked by FEG-SEM. The grinded raw material and the residues from the muffle treatment at $550{ }^{\circ} \mathrm{C}$ and the $\mathrm{NaOH}$ hydrolysis were also analyzed for comparison. The obtained micrographs are shown in Figure 6.

As shown in Figure 6a, the grinded raw bone has a solid surface with porous regions that might correspond to the internal surfaces of fractured bones. The morphology of some of the particles still preserves characteristics of the original codfish frames and some fibrillar structures, possibly from the adhered muscle, can be observed.

The effect of the SBW process can be observed in Figure 6b. In this case, the original morphology of the codfish frames is not present. Some large, irregular bone fragments can be observed but the SBW residue mostly consists of small particles agglomerated in clusters with sizes ranging from 0.1 to $10 \mu \mathrm{m}$. This morphology was also observed by Barakat et al. [41]. Subcritical water was able to dissolve the protein and other organic compounds nearly completely in the bone matrix, leaving the hydroxyapatite powder observed in Figure 6b.

For the residues of the thermal decomposition at $550{ }^{\circ} \mathrm{C}$ and the alkaline hydrolysis processes, the obtained morphologies are shown in Figure $6 c, d$, respectively. From Figure $6 c$, it seems that the thermal decomposition process preserves the morphology of the original codfish frames, since large and irregular particles have been obtained. No fibrillar structures or porous surfaces were observed, indicating that organic matter is removed with this treatment. Contrary to the results obtained in this work, Barakat et al. obtained HAp particles with nanorod shape and average size of $300 \mathrm{~nm}$, although they used higher temperatures for the thermal decomposition $\left(750^{\circ} \mathrm{C}\right)$ which likely promoted the crystallization process [41]. On the other hand, the alkaline hydrolysis has similar effect to that of the SBW process. As shown in Figure $6 \mathrm{~b}, \mathrm{~d}$, both processes produced small hydroxyapatite flakes although larger particles were observed in the case of the alkaline hydrolysis process. 
(a)
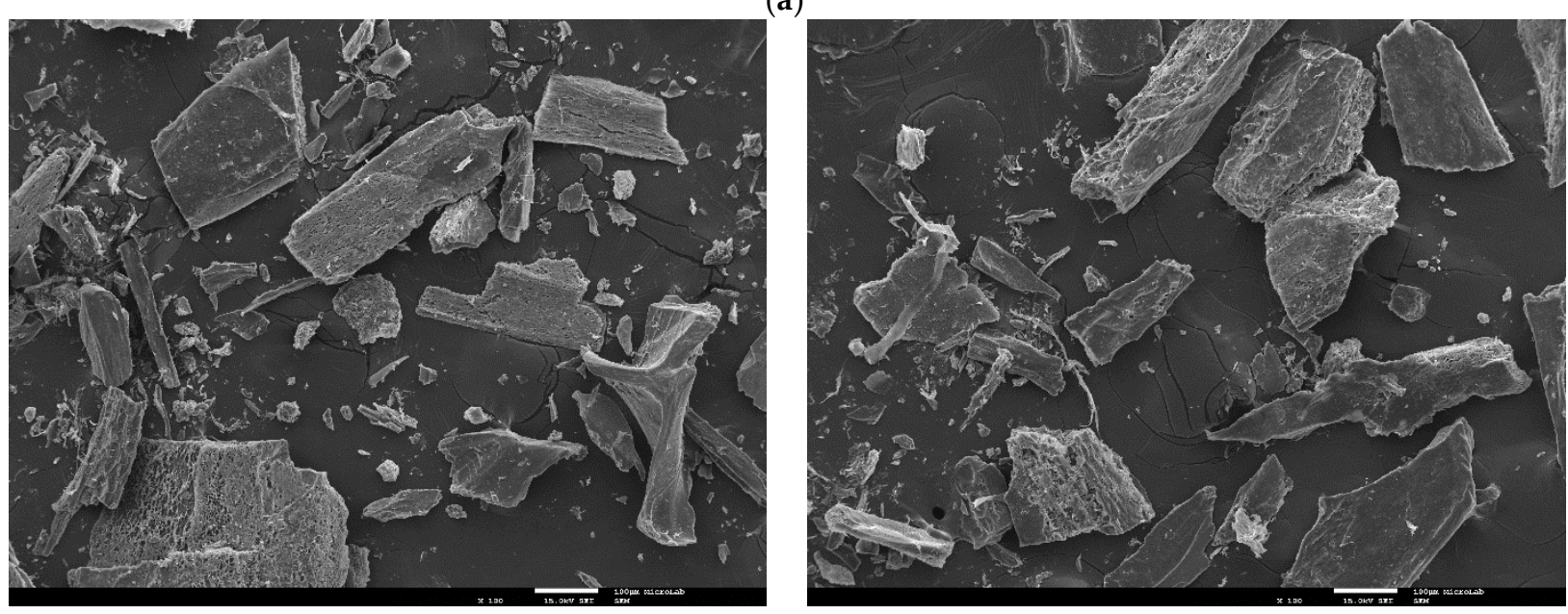

(b)
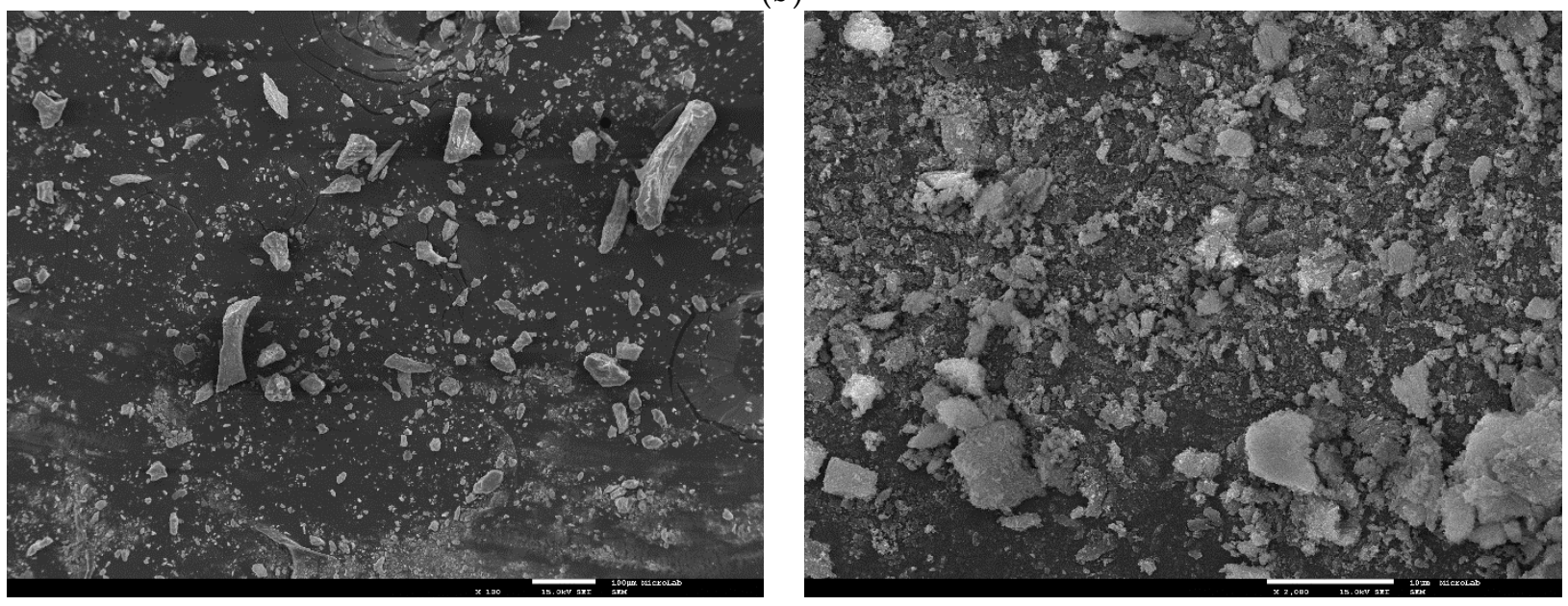

(c)
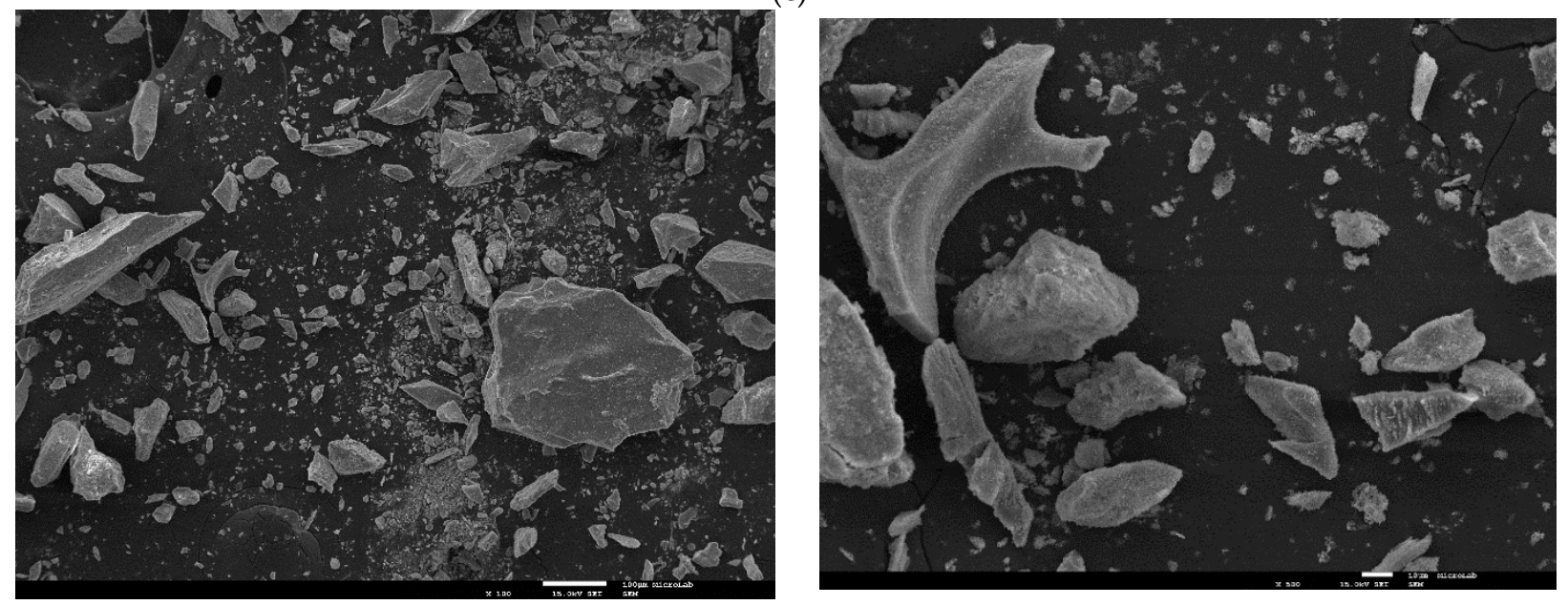

Figure 6. Cont. 
(d)
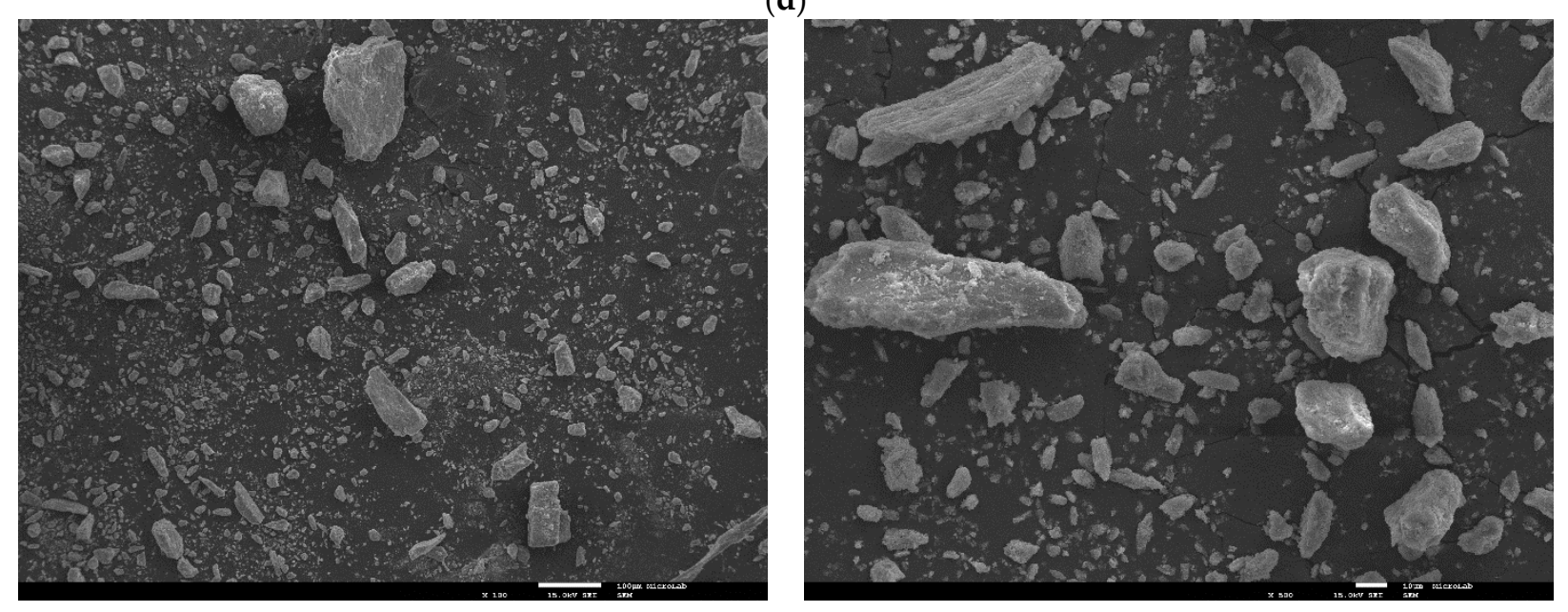

Figure 6. FEG-SEM micrographs of (a) grinded codfish frames $(100 \times$ and $500 \times)$; (b) codfish frames after subcritical water treatment $(100 \times$ and $2000 \times)$; (c) codfish frames after thermal decomposition at $550{ }^{\circ} \mathrm{C}(100 \times$ and $500 \times)$; (d) codfish frames after alkaline hydrolysis $(100 \times$ and $500 \times)$.

Complementarily to the FEG-SEM analysis, energy-dispersive $\mathrm{X}$-ray analysis was performed in different surface areas of the obtained HAp powders. Results are shown in Supplementary Figures S2-S5. According to the chemical formula of the standard hydroxyapatite, the calcium to phosphorous molar ratio is approximately 1.67. The EDS analysis gave average $\mathrm{Ca} / \mathrm{P}$ ratios of $1.62 \pm 0.21,1.90 \pm 0.5$, and $1.51 \pm 0.1$ for the residues obtained by SBW process, thermal decomposition at $550{ }^{\circ} \mathrm{C}$, and alkaline hydrolysis, respectively. All the obtained values lie within the acceptable range for hydroxyapatite [56]. In the case of the raw codfish frames, $\mathrm{Ca}$ and $\mathrm{P}$ and other minerals commonly present in HAp were not detected in the surface of the raw codfish frames, likely because the protein matrix dispersed the $\mathrm{X}$-ray radiation. The eventual presence of elements $\mathrm{Na}$ and $\mathrm{Cl}$ in the residues is interesting to check since their presence or absence may be related to the different treatment methods. $\mathrm{Na}$ and $\mathrm{Cl}$ were not detected in the SBW residue since they were solubilized and removed by the subcritical water treatment. However, $\mathrm{Na}$ and $\mathrm{Cl}$ were present in the residue from the thermal decomposition at $550{ }^{\circ} \mathrm{C}$, whereas for the residue from the alkaline hydrolysis the element $\mathrm{Cl}$ was absent and $\mathrm{Na}$ residues from the $\mathrm{NaOH}$ treatment were detected.

\section{Conclusions}

The results presented in this study demonstrate the feasibility of the integral valorization of codfish (Gadus morhua) frames. Using green extraction methods such as subcritical water extraction and hydrolysis (SBW), codfish frames were fractionated into their main constituents, namely proteins and minerals, each of them with promising applications in the food, pharmaceutical, biomedical, and cosmetic industries. Proteins in codfish frames were almost entirely recovered as aqueous extracts, obtaining peptides of decreasing molecular weight when increasing the extraction temperature from 90 to $250{ }^{\circ} \mathrm{C}$. The protein extracts were non-cytotoxic in a model for crypt enterocytes (Caco-2 cells), yet they showed high anti-inflammatory potential in human intestinal epithelium cell mode. The main constituent of the mineral fraction, hydroxyapatite, was isolated in an almost pure and crystalline form; its potential applications are currently under study. In view of these results, it is clear that the proposed SBW process promotes a more effective use of the waste generated during codfish processing.

Supplementary Materials: The following are available online at https:/ / www.mdpi.com/article/10 .3390 / foods10061222/s1, Figure S1: SEC-GPC chromatograms of the extracts obtained by subcritical water hydrolysis of codfish frames at (a) $90^{\circ} \mathrm{C}$, (b) $140{ }^{\circ} \mathrm{C}$, (c) $190^{\circ} \mathrm{C}$, and (d) $250{ }^{\circ} \mathrm{C}$, Figure S2: 
Energy-dispersive X-ray analysis of the grinded codfish frames, Figure S3: Energy-dispersive X-ray analysis of the codfish frames after subcritical water treatment, Figure S4: Energy-dispersive X-ray analysis of the codfish frames after thermal decomposition at $550{ }^{\circ} \mathrm{C}$, Figure S5: Energy-dispersive $\mathrm{X}$-ray analysis of the codfish frames after alkaline hydrolysis.

Author Contributions: Conceptualization, P.S., A.P. and R.M.; methodology, R.M. and N.F.; validation, A.P., I.S.-N., N.F. and P.S.; formal analysis, R.M., M.M. and A.B.; investigation, R.M., M.M. and A.B.; data curation, R.M., M.M. and A.B.; writing-original draft preparation, R.M.; writing-review and editing, P.S.; visualization, R.M.; supervision, I.S.-N., N.F. and P.S.; project administration, P.S.; funding acquisition, P.S. All authors have read and agreed to the published version of the manuscript.

Funding: This research was funded by the Associate Laboratory for Green Chemistry-LAQV which is financed by national funds from FCT/MCTES (UIDB/QUI/50006/2020), by Applied Molecular Biosciences Unit-UCIBIO which is financed by national funds from FCT/MCTES (UIDP/04378/2020 and UIDB/04378/2020), by Fundação para a Ciência e a Tecnologia through project PTDC/ASPPES/28399/2017 and iNOVA4Health-UIDB/04462/2020 and UIDP/04462/2020, a program financially supported by Fundação para a Ciência e Tecnologia/Ministério da Ciência, Tecnologia e Ensino Superior, through national funds. Funding from INTERFACE Programme, through the Innovation, Technology and Circular Economy Fund (FITEC), is gratefully acknowledged. AP was funded by Fundação para a Ciência e a Tecnologia through project IF/01146/2015.

Data Availability Statement: Not applicable.

Acknowledgments: We acknowledge the help of Nuno Costa and Carla Rodrigues from Laboratório de Análises (LAQV, REQUIMTE).

Conflicts of Interest: The authors declare no conflict of interest.

\section{References}

1. Instituto Nacional de Estatística-Estatísticas da Pesca: 2019; INE: Lisbon, Portugal, 2020; ISBN 978-989-25-0540-4. Available online: https:/ / www.ine.pt/xurl/pub/435690295 (accessed on 1 March 2021).

2. Toppe, J.; Albrektsen, S.; Hope, B.; Aksnes, A. Chemical composition, mineral content and amino acid and lipid profiles in bones from various fish species. Comp. Biochem. Physiol. B Biochem. Mol. Biol. 2007, 146, 395-401. [CrossRef]

3. Lordan, S.; Ross, R.P.; Stanton, C. Marine bioactives as functional food ingredients: Potential to reduce the incidence of chronic diseases. Mar. Drugs 2011, 9, 1056-1100. [CrossRef]

4. Kim, S.K.; Mendis, E. Bioactive compounds from marine processing byproducts-A review. Food Res. Int. 2006, 39, 383-393. [CrossRef]

5. Ghaly, A.E.; Ramakrishnan, V.V.; Brooks, M.S.; Budge, S.M.; Dave, D. Fish processing wastes as a potential source of proteins, amino acids and oils: A critical review. J. Microb. Biochem. Technol. 2013, 5, 107-129. [CrossRef]

6. Kristinsson, H.G.; Rasco, B.A. Fish Protein Hydrolysates: Production, Biochemical, and Functional Properties. Crit. Rev. Food Sci. Nutr. 2020, 40, 43-81. [CrossRef] [PubMed]

7. Huang, C.Y.; Kuo, J.M.; Wu, S.J.; Tsai, H.T. Isolation and characterization of fish scale collagen from tilapia (Oreochromis sp.) by a novel extrusion-hydro-extraction process. Food Chem. 2016, 190, 997-1006. [CrossRef] [PubMed]

8. Jafarpour, A.; Gomes, R.M.; Gregersen, S.; Sloth, J.J.; Jacobsen, C.; Moltke Sørensen, A.D. Characterization of cod (Gadus morhua) frame composition and its valorization by enzymatic hydrolysis. J. Food Compos. Anal. 2020, 89, 103469. [CrossRef]

9. Kim, H.K.; Kim, Y.H.; Kim, Y.J.; Park, H.J.; Lee, N.H. Effects of ultrasonic treatment on collagen extraction from skins of the sea bass Lateolabrax Japonicus. Fish. Sci. 2012, 78, 485-490. [CrossRef]

10. He, G.; Yan, X.; Wang, X.; Wang, Y. Extraction and structural characterization of collagen from fishbone by high intensity pulsed electric fields. J. Food Process Eng. 2019, 42, 1-9. [CrossRef]

11. Dorozhkin, S.V. Bioceramics of calcium orthophosphates. Biomaterials 2010, 31, 1465-1485. [CrossRef]

12. Mucalo, M. (Ed.) Hydroxyapatite (Hap) for Biomedical Applications, 1st ed.; Woodhead Publishing: Cambridge, UK, 2015. [CrossRef]

13. Feng, Y.; Yang, J.; Liu, W.; Yan, Y.; Wang, Y. Hydroxyapatite as a passivator for safe wheat production and its impacts on soil microbial communities in a Cd-contaminated alkaline soil. J. Hazard. Mater. 2021, 404, 124005. [CrossRef] [PubMed]

14. Mori, K.; Hara, T.; Mizugaki, T.; Ebitani, K.; Kaneda, K. Hydroxyapatite-supported palladium nanoclusters: A highly active heterogeneous catalyst for selective oxidation of alcohols by use of molecular oxygen. J. Am. Chem. Soc. 2004, 126, 10657-10666. [CrossRef] [PubMed]

15. Chen, F.F.; Zhu, Y.J.; Chen, F.; Dong, L.Y.; Yang, R.L.; Xiong, Z.C. Fire alarm wallpaper based on fire-resistant hydroxyapatite nanowire inorganic paper and graphene oxide thermosensitive sensor. ACS Nano 2018, 12, 3159-3171. [CrossRef] [PubMed]

16. Bee, S.L.; Hamid, Z.A.A. Hydroxyapatite derived from food industry bio-wastes: Syntheses, properties and its potential multifunctional applications. Ceram. Int. 2020, 46, 17149-17175. [CrossRef] 
17. Lü, X.Y.; Fan, Y.B.; Gu, D.; Cui, W. Preparation and characterization of natural hydroxyapatite from animal hard tissues. Key Eng. Mater. 2007, 342-343, 213-216. [CrossRef]

18. Ofudje, E.A.; Rajendran, A.; Adeogun, A.I.; Idowu, M.A.; Kareem, S.O.; Pattanayak, D.K. Synthesis of organic derived hydroxyapatite scaffold from pig bone waste for tissue engineering applications. Adv. Powder Technol. 2018, 29, 1-8. [CrossRef]

19. Bee, S.L.; Hamid, Z.A.A. Characterization of chicken bone waste-derived hydroxyapatite and its functionality on chitosan membrane for guided bone regeneration. Compos. Part B Eng. 2019, 163, 562-573. [CrossRef]

20. Abdulrahman, I.; Tijani, H.I.; Mohammed, B.A.; Saidu, H.; Yusuf, H.; Ndejiko Jibrin, M.; Mohammed, S. From garbage to biomaterials: An overview on egg shell based hydroxyapatite. J. Mater. 2014, 2014, 1-6. [CrossRef]

21. Piccirillo, C.; Silva, M.F.; Pullar, R.C.; Braga Da Cruz, I.; Jorge, R.; Pintado, M.M.E.; Castro, P.M.L. Extraction and characterisation of apatite- and tricalcium phosphate-based materials from cod fish bones. Mater. Sci. Eng. C 2013, 33, 103-110. [CrossRef]

22. Ozawa, M.; Suzuki, S. Microstructural development of natural hydroxyapatite originated from fish-bone waste through heat treatment. J. Am. Ceram. Soc. 2002, 85, 1315-1317. [CrossRef]

23. Wu, S.C.; Hsu, H.C.; Hsu, S.K.; Tseng, C.P.; Ho, W.F. Preparation and characterization of hydroxyapatite synthesized from oyster shell powders. Adv. Powder Technol. 2017, 28, 1154-1158. [CrossRef]

24. Huang, Y.C.; Hsiao, P.C.; Chai, H.J. Hydroxyapatite extracted from fish scale: Effects on MG63 osteoblast-like cells. Ceram. Int. 2011, 37, 1825-1831. [CrossRef]

25. Muhammad, N.; Gao, Y.; Iqbal, F.; Ahmad, P.; Ge, R.; Nishan, U.; Rahim, A.; Gonfa, G.; Ullah, Z. Extraction of biocompatible hydroxyapatite from fish scales using novel approach of ionic liquid pretreatment. Sep. Purif. Technol. 2016, 161, 129-135. [CrossRef]

26. Brunner, G. Hydrothermal and Supercritical Water Processing of Inorganic Substances. Supercrit. Fluid Sci. Technol. 2014, 5, 569-589.

27. Pedras, B.; Salema-Oom, M.; Sá-nogueira, I.; Simões, P.; Paiva, A.; Barreiros, S. Valorization of white wine grape pomace through application of subcritical water: Analysis of extraction, hydrolysis, and biological activity of the extracts obtained. J. Supercrit. Fluids 2017, 128, 138-144. [CrossRef]

28. Cocero, M.J.; Cabeza, Á.; Abad, N.; Adamovic, T.; Vaquerizo, L.; Martínez, C.M.; Pazo-Cepeda, M.V. Understanding biomass fractionation in subcritical \& supercritical water. J. Supercrit. Fluids 2018, 133, 550-565. [CrossRef]

29. Yoshida, H.; Terashima, M.; Takahashi, Y. Production of organic acids and amino acids from fish meat by sub-critical water hydrolysis. Biotechnol. Prog. 1999, 15, 1090-1094. [CrossRef] [PubMed]

30. Kang, K.Y.; Chun, B.S. Behavior of amino acid production from hydrothermal treatment of fish-derived wastes. Korean J. Chem. Eng. 2004, 21, 1147-1152. [CrossRef]

31. Daimon, H.; Kang, K.; Sato, N.; Fujie, K. Development of marine waste recycling technologies using sub- and supercritical water. J. Chem. Eng. Jpn. 2001, 34, 1091-1096. [CrossRef]

32. Uddin, S.; Ahn, H.; Kishimura, H.; Chun, B. Production of valued materials from squid viscera by subcritical water hydrolysis. J. Environ. Biol. 2010, 31, 675-679. [PubMed]

33. Kim, R.-H.; Asaduzzaman, A.K.M.; You, C.-H.; Chun, B.-S. Stability of antioxidant properties and essential amino acids in squid viscera hydrolysate produced using subcritical water. Fish. Aquat. Sci. 2013, 16, 71-78. [CrossRef]

34. Choi, J.; Moon, H.E.; Roh, M.-K.; Ha, Y.-M.; Lee, B.-B.; Cho, K.K.; Choi, I.S. Physiological properties of Scomber japonicus meat hydrolysate prepared by subcritical water hydrolysis. J. Environ. Biol. 2016, 37, 57-63. [PubMed]

35. Asaduzzaman, A.K.M.; Getachew, A.T.; Cho, Y.J.; Park, J.S.; Haq, M.; Chun, B.S. Characterization of pepsin-solubilised collagen recovered from mackerel (Scomber japonicus) bone and skin using subcritical water hydrolysis. Int. J. Biol. Macromol. 2020, 148, 1290-1297. [CrossRef]

36. Asaduzzaman, A.K.M.; Chun, B.-S. Hydrolyzates produced from mackerel Scomber japonicus skin by the pressurized hydrothermal process contain amino acids with antioxidant activities and functionalities. Fish. Sci. 2014, 80, 369-380. [CrossRef]

37. Ueno, S.; Ichinoi, H.; Zhao, J.; Fujii, T. Degradation of fish gelatin using hot-compressed water and the properties of the degradation products. High Press. Res. 2015, 35, 203-213. [CrossRef]

38. Cho, Y.; Haq, M.; Park, J.; Lee, H.; Chun, B. Physicochemical and biofunctional properties of shrimp (Penaeus japonicus) hydrolysates obtained from hot-compressed water treatment. J. Supercrit. Fluids 2019, 147, 322-328. [CrossRef]

39. Ahmed, R.; Chun, B. Subcritical water hydrolysis for the production of bioactive peptides from tuna skin collagen. J. Supercrit. Fluids 2018, 141, 88-96. [CrossRef]

40. Melgosa, R.; Trigueros, E.; Sanz, M.T.; Cardeira, M.; Rodrigues, L.; Fernández, N.; Matias, A.A.; Bronze, M.R.; Marques, M.; Paiva, A.; et al. Supercritical $\mathrm{CO}_{2}$ and subcritical water technologies for the production of bioactive extracts from sardine (Sardina pilchardus) waste. J. Supercrit. Fluids 2020, 164. [CrossRef]

41. Barakat, N.A.M.; Khil, M.S.; Omran, A.M.; Sheikh, F.A.; Kim, H.Y. Extraction of pure natural hydroxyapatite from the bovine bones bio waste by three different methods. J. Mater. Process. Technol. 2009, 209, 3408-3415. [CrossRef]

42. Espíndola-Cortés, A.; Moreno-Tovar, R.; Bucio, L.; Gimeno, M.; Ruvalcaba-Sil, J.L.; Shirai, K. Hydroxyapatite crystallization in shrimp cephalothorax wastes during subcritical water treatment for chitin extraction. Carbohydr. Polym. 2017, 172, 332-341. [CrossRef] [PubMed]

43. Bligh, E.G.; Dyer, W.J. A rapid method of total lipid extraction and purification. Can. J. Biochem. Physiol. 1959, 37, 911-917. [CrossRef] 
44. Sluiter, J.B.; Ruiz, R.O.; Scarlata, C.J.; Sluiter, A.D.; Templeton, D.W. Compositional analysis of lignocellulosic feedstocks. 1. Review and description of methods. J. Agric. Food Chem. 2010, 58, 9043-9053. [CrossRef]

45. Neuman, R.E.; Logan, M.A. The determination of collagen and elastin in tissues. J. Biol. Chem. 1950, 186, 549-556. [CrossRef]

46. Laemmli, U.K. Cleavage of Structural Proteins during the Assembly of the Head of Bacteriophage T4. Nature 1970, 227, 680-685. [CrossRef] [PubMed]

47. Rodrigues, L.; Silva, I.; Poejo, J.; Serra, A.T.; Matias, A.A.; Simplício, A.L.; Bronze, M.R.; Duarte, C.M.M. Recovery of antioxidant and antiproliferative compounds from watercress using pressurized fluid extraction. RSC Adv. 2016, 6, 30905-30918. [CrossRef]

48. Smith, A.L. The Coblentz Society Desk Book of Infrared Spectra, 2nd ed.; Carver, C.D., Ed.; The Coblentz Society: Kirkwood, MO, USA, 1982.

49. SRM 2910b. Hydroxyapatite; National Institute of Standards and Technology, U.S. Department of Commerce: Gaithersburg, MD, USA, 2015.

50. Mæhre, H.K.; Dalheim, L.; Edvinsen, G.K.; Elvevoll, E.O.; Jensen, I.J. Protein determination—Method matters. Foods 2018, 7, 5. [CrossRef]

51. Sosulski, F.W.; Imafidon, G.I. Amino acid composition and nitrogen-to-protein conversion factors for animal and plant foods. J. Agric. Food Chem. 1990, 38, 1351-1356. [CrossRef]

52. Mariotti, F.; Tomé, D.; Mirand, P.P. Converting nitrogen into protein-Beyond 6.25 and Jones' factors. Crit. Rev. Food Sci. Nutr. 2008, 48, 177-184. [CrossRef] [PubMed]

53. Gauza-Włodarczyk, M.; Kubisz, L.; Włodarczyk, D. Amino acid composition in determination of collagen origin and assessment of physical factors effects. Int. J. Biol. Macromol. 2017, 104, 987-991. [CrossRef] [PubMed]

54. Carvalho, A.M.; Marques, A.P.; Silva, T.H.; Reis, R.L. Evaluation of the potential of collagen from codfish skin as a biomaterial for biomedical applications. Mar. Drugs 2018, 16, 495. [CrossRef] [PubMed]

55. Sadowska, M.; Kołodziejska, I.; Niecikowska, C. Isolation of collagen from the skins of Baltic cod (Gadus morhua). Food Chem. 2003, 81, 257-262. [CrossRef]

56. Francis, M.D.; Webb, N.C. Hydroxyapatite formation from a hydrated calcium monohydrogen phosphate precursor. Calcif. Tissue Res. 1970, 6, 335-342. [CrossRef] [PubMed]

57. Abdelmoez, W.; Nakahasi, T.; Yoshida, H. Amino acid transformation and decomposition in saturated subcritical water conditions. Ind. Eng. Chem. Res. 2007, 46, 5286-5294. [CrossRef]

58. Joint FAO/WHO Codex Alimentarius Commission. Codex Standard CDX 193-1995, General Standard for Contaminants and Toxins in Food and Feed; Food and Agriculture Organization of the United Nations: Rome, Italy, 1995; last revised 2019.

59. Liu, D.; Liang, L.; Regenstein, J.M.; Zhou, P. Extraction and characterisation of pepsin-solubilised collagen from fins, scales, skins, bones and swim bladders of bighead carp (Hypophthalmichthys nobilis). Food Chem. 2012, 133, 1441-1448. [CrossRef]

60. Sotelo, C.G.; Comesaña, M.B.; Ariza, P.R.; Pérez-Martín, R.I. Characterization of collagen from different discarded fish species of the west coast of the Iberian Peninsula. J. Aquat. Food Prod. Technol. 2016, 25, 388-399. [CrossRef]

61. Chi, C.F.; Cao, Z.H.; Wang, B.; Hu, F.Y.; Li, Z.R.; Zhang, B. Antioxidant and functional properties of collagen hydrolysates from Spanish mackerel skin as influenced by average molecular weight. Molecules 2014, 19, 11211-11230. [CrossRef] [PubMed]

62. Koomyart, I.; Nagamizu, H.; Khuwijitjaru, P.; Kobayashi, T.; Shiga, H.; Yoshii, H.; Adachi, S. Subcritical water treatment for producing seasoning from semidried Isada krill. J. Food Process Eng. 2014, 37, 567-574. [CrossRef]

63. Hart, M.J.; Torres, S.J.; McNaughton, S.A.; Milte, C.M. Dietary patterns and associations with biomarkers of inflammation in adults: A systematic review of observational studies. Nutr. J. 2021, 20, 1-14. [CrossRef] [PubMed]

64. Matias, A.; Nunes, S.L.; Poejo, J.; Mecha, E.; Serra, A.T.; Madeira, P.J.A.; Bronze, M.R.; Duarte, C.M.M. Antioxidant and anti-inflammatory activity of a flavonoid-rich concentrate recovered from Opuntia ficus-indica juice. Food Funct. 2014, 5, 3269-3280. [CrossRef]

65. Chevrier, G.; Mitchell, P.L.; Rioux, L.E.; Hasan, F.; Jin, T.; Roblet, C.R.; Doyen, A.; Pilon, G.; St-Pierre, P.; Lavigne, C.; et al Low-molecular-weight peptides from salmon protein prevent obesity-linked glucose intolerance, inflammation, and dyslipidemia in LDLR-/-/ApoB100/100 mice. J. Nutr. 2015, 145, 1415-1422. [CrossRef]

66. Zhang, Z.; Hu, X.; Lin, L.; Ding, G.; Yu, F. Immunomodulatory activity of low molecular-weight peptides from Nibea japonica skin in RAW264.7 cells via NF-kB pathway. Mar. Drugs 2019, 17, 404. [CrossRef] [PubMed]

67. Chang, M.C.; Tanaka, J. FT-IR study for hydroxyapatite/collagen nanocomposite cross-linked by glutaraldehyde. Biomaterials 2002, 23, 4811-4818. [CrossRef] 